\title{
FOUNDATIONS AND TRENDS IN ANALYTICS AND MARKETING RELATIONSHIP
}

\author{
Alamir Costa Louro \\ Ph.D In Business Administration \\ Universidade Federal do Espírito Santo - UFES. \\ alamirlouro@gmail.com \\ (D) Marcelo Moll Brandão \\ $\mathrm{Ph} . \mathrm{D}$ In Business Administration \\ Universidade Federal do Espírito Santo - UFES. \\ Vitória, ES- Brasil. \\ Mollmkt@gmail.com \\ Arthur França Sarcinelli \\ Master In Business Administration \\ Universidade Federal do Espírito Santo - UFES. \\ Vitória, ES- Brasil. \\ thearthursarcinelli@gmail.com
}

Purpose: The purpose of this paper is to pave the path for further quantitative research in the field of analytics in marketing based on capabilities literature, it analyzed state of the art about Analytics and Marketing in the context of Resource-Based View and capabilities literature.

Design/methodology/approach: It is a bibliometric and an applied review that shows the relationship between the subfields. We used some cluster analyses to provide a scheme for tracking this literature intersection for beginners and experienced researchers.

Findings: After the adaptive analytics capabilities proposition, the paper is concluded with a discussion of pathways in Marketing and Strategy literature indicating possible endogenous, exogenous, and covariate constructs for moderation/mediation mechanism studies agenda.

Research implications: It was developed a nomological network for construct choice process aiming for future studies of the emerging relationship between Marketing, Analytics, and Capabilities using updated and relevant constructs references.

Originality/value: From the foundations of Analytics and Marketing intersection, we gave objective trends and constructs to develop a future agenda that can intertwine the subfields using the power of dynamic capabilities literature.

Keywords: Bibliometric. Analytics. Marketing. Capabilities.

\section{How to cite the article}

American Psychological Association (APA)

Brandão, M. M., Louro, A. C., \& Sarcinelli, A. F. (2021, Jan./Mar.). Foundations and trends in analytics and marketing relationship. Brazilian Journal of Marketing, 20(1), 1-25. https://doi.org/10.5585/remark.v20i1.17554 


\section{Introduction}

Market dynamics, including its dialectic process of (de) regulation, (de) globalization, the last thirty-year information technology (IT) commoditization, the recent emergence of new revolutionary technology and national and international political uncertainties, beyond the cultural differences (Conti, Parente, \& de Vasconcelos, 2015), alters the environmental dynamism and competitive advantage search.

The advanced analysis with a marketing emphasis, denominated in the present work as marketing analytics, helps to transform internal or external data, structured or not, in strategic information. It demands some in-depth marketing modeling techniques for the market's response prediction, optimization of marketing-mix, and personalization for the customers (Wedel \& Kannan, 2016). Data mining in texts, voice, video, digital media, or websites is a technology that helps organizations, providing insights that are used to adjust business rules and to create relationships with customers in a more relevant and connected way (Cooke \& Zubcsek, 2017).

Analytics, as a field of study, has been gaining momentum in the last two decades, both in business and academic realms (Chen, Chiang \& Storey, 2012). A search on Google Scholar in October 2019, with the keywords 'marketing' and 'analytics,' brought more than 470 thousand hits, with most of them consisting of recent publications.

Some updated literature already predicts, for some industries, that emergent technologies and analytics will be enablers of competitive advantage and the organizations need to understand their data and prepare it for a more efficient use (Côrte-real, Oliveira, \& Ruivo, 2017; Wang \& Hajli, 2017; Braganza, Brooks, Nepelski, Ali, \& Moro, 2017).

The development of new products (Xu, Frankwick, \& Ramirez, 2016), instant and recurrent feedback from transactions made by customers (Cooke \& Zubcsek, 2017), and shared insights or co-creation innovation with customers (Khanagha, Volberda, \& Oshri, 2017) are examples of activities supported by analytics technologies. There are also pricing and promotion, marketing mix, customer lifecycle value (Germann, Lilien, Fiedler, \& Kraus, 2014), advertisement, salesforce, branding, positioning, and market segmentation, all guided toward data (Wedel \& Kannan, 2016). From this, we can see that using analytics and analytical technologies for marketing has attracted much focus in research throughout the years, yet we can still notice a lack of full understanding of how the capabilities can associate analytics and marketing with performance. Therefore, the purpose of this study is to pave the path for further quantitative research in the field of analytics in marketing based on 
capabilities literature by suggesting the nomological network. For that, the paper addresses the following research questions:

RQ1. How did the core knowledge at the intersection of marketing and analytics evolve through time, and what are the core topics and trends today?

RQ2. What are the main research opportunities or issues when it comes to marketing capabilities?

RQ3. What are the potential exogenous, covariates, intervenients, and concurrent endogenous constructs for studying the impact of adaptive analytics capabilities (proposed construct) on organizational performance?

The present first presents the development of the analytics research, with the focus on its use in marketing; then, it is presented some descriptive bibliometric results, after two cluster analysis for author coupling and keyword co-occurrence; then it is established a systematic review of recent quantitative papers from where, finally, it is proposed a nomological network that shows the pathways to improve quantitative research in marketing strategy using analytics.

\section{Marketing and analytics duo: foundations}

The present work provides a twenty-year summary of the analytics development as a research field while highlighting the major strengths of combining this area with marketing, especially from the perspective of the capabilities literature.

The broad term analytics is considered a young but increasingly important field of study, mainly characterized as the set of techniques, tools, and approaches aiming at accurate analysis of business data to improve decision-making. The evolution of this multidisciplinary field can be simplified into three major time periods, as proposed by Chen et al. (2012) framework: BI\&A 1.0, BI\&A 2.0, and BI\&A 3.0.

The first period occurs in the 1990s, where the combination of statistical techniques and data mining practices lead to the development of better analytical tools, designed for the extraction and storage of data into robust databases (Chen et al., 2012). Therefore, the goal of marketing professionals was to optimize the collection, structuring, and later analysis of the data available in the market.

The second period begins with the popularization of the Internet on a global scale, which drastically transformed the way data is shared and expanding the volume of information that can be accessed. This scenario can be described as a big opportunity for 
marketers, since the shift towards digital communication impacts on the marketing mix formula (Germann et al., 2014; Wedel \& Kannan, 2016), changing the main channels used to produce advertising and customer relationship management.

The third and most recent period is directly related to the so-called internet of things (IoT) and big data phenomena. This opens a new perspective on how new high-tech products can be used as a data source to provide useful and individualized information to enhance market knowledge, though it also brings uncertainty about the best techniques and approaches to collect, process, and analyze data (Chen et al., 2012).

The work of Chen et al. (2012) provides insightful information about how the area of BI\&A evolved since its inception. Parallel to that, it is necessary to have business strategy discussions, primarily related to the resource-based view (Barney, 2014) and capabilities literature. In the marketing field, e-commerce and market intelligence subareas are the candidates to benefit the most from all sources of analytical tools (Chen et al., 2012). But, how can those analytical tools/methods/approaches be viewed as a proper capability, which is able to achieve performance?

\section{Bibliometric review}

It was performed a bibliometric study in Scopus and Web of Science bases to analyze the state of the art that relates marketing and analytics. The sample criteria were created using "marketing AND analytics AND (capabilities OR resources)"as the search string in titles, abstracts, and keywords. English only, and with no period of time limit criteria. The keywords capabilities or resources were chosen for the theoretical delimitation of the present work, which used the resource-based view and its underlying literature about capabilities as cornerstones.

It was confirmed that the extracted articles are adherent to the research delimitation with a search based on the titles, abstracts, and keywords. Those were passed onto a spreadsheet, from where other theories were found with low occurrences, such as the configuration theory, game theory, innovations theory, while, with a bigger number of occurrences, it was perceived capabilities, Resource-Based Theory, or Resource-Based View (RBV).

According to Quevedo-Silva, Santos, Brandão, and Vils (2016), the bibliometric method brings a broader comprehension of themes or areas, allowing the identification of trends. According to the bibliographic review of those authors, this type of study performs 
three, mutually non-exclusive, approaches: (i) descriptive, that draws broad lines or the most studied topics in an area, identifying research groups, publication year, leading authors and methods used; (ii) about methodology, which ought to understand the methodological domain of the researched area by classifying and counting the research drawings and the test techniques mostly used, adjacently, it aims to find study opportunities and highlight a determined area research tradition; lastly the approach of (iii) descriptive analysis, which deepens the knowledge using cluster analysis of authors, theories, and keywords from the sample metadata.

The descriptive step was used to introduce the present bibliometric study, but the second step was not performed with a bibliometric approach, due to the research delimitation. Regarding the methodological domain, it was not carried out on all 705 articles, because it was chosen to perform this analysis in a much more detailed manner, beginning with a shorter list presented in the applied research section. Finally, the last step, cluster analysis, is shown as research trends.

\section{Descriptive step}

The tables from 1 to 5 represent (i) a descriptive approach. And, the analytical approach (iii) was primarily achieved with the usage of clusters about co-citations, cooccurrence, and coupling information from authors and keywords. Besides that, it was from these clusters analysis that one started to associate marketing and analytics using capabilities literature.

Table 1 - Bibliometric results - general description

\begin{tabular}{lc|lc}
\hline Main Information about data & & & \\
\hline Articles & 898 & Authors of single-authored articles & 138 \\
\hline Sources (Journals) & 412 & Authors of multi-authored articles & 1479 \\
\hline Journal Keywords & 1980 & Articles per Author index & 0.547 \\
\hline $\begin{array}{l}\text { Author's } \\
2014\end{array}$ & Keywords & Authors per Article index & 1.82 \\
\hline Average citations per article & & & \\
\hline First Authors & 9.321 & Co-Authors per Articles index & 2.71 \\
\hline Author Appearances & 1641 & Collaboration Index & 2.36 \\
\hline Scopus articles & 1999 & Period & $1972-2019$ \\
\hline
\end{tabular}

Source: Prepared by the author (2019). Using the R software.

Table 1 describes the basic information from this sample since 1972; detailed information by year is presented in Table 2. It is highlighted that there were only included 
journal articles excluding revisions and conference papers, workshops, editorials, and tutorials. From a total of 898 , counting the two bases of extraction, and after the exclusion of repetitions, it resulted in 778 articles. The exclusion of articles was executed by "mergeDbSources" function of the "bibliometrix" package (Aria \& Cuccurullo, 2017).

Table 1 also describes the number of articles in Scopus and Web of Science, the number of sources, keywords used by authors and journals, authors, and some indexes that relate this information with each other.

Table 2 - Number of articles annual evolution

\begin{tabular}{ccccccccccccc}
\hline \multicolumn{10}{c}{ Annual Scientific Production } \\
\hline Year & $\begin{array}{c}1972- \\
2008\end{array}$ & 2009 & 2010 & 2011 & 2012 & 2013 & 2014 & 2015 & 2016 & 2017 & 2018 \\
\hline Articles & 72 & 26 & 27 & 22 & 42 & 50 & 74 & 101 & 152 & 128 & 161 \\
\hline \multicolumn{10}{c}{ Annual Percentage Growth Rate 3.93 } \\
\hline
\end{tabular}

Source: Prepared by the author (2019). Using the R software.

In fact, from 1972 until the year 2008, only 72 articles were found in the sample, so the last decade grouped around $92 \%$ of the articles in the sample. The year 2019 was excluded from the table, but it presented49 published articles. The bibliometrix package (Aria \& Cuccurullo, 2017) used by the software R (R Core Team, 2019) calculated that there is positive annual growth, demonstrating an increasing interest in the topic.

The information in Table 3 demonstrates that Brazil is not one of the central countries in the productions and citations of this area. Extending the search, Brazil was found in the 18th position of the ranking.

Table 3 - Most productive countries

\begin{tabular}{|c|c|c|c|c|c|c|}
\hline \multicolumn{3}{|c|}{ Total Papers per Country } & \multicolumn{4}{|c|}{ Total Citations per Country } \\
\hline & COUNTRY & ARTICLES & FREQ & COUNTRY & CITATIONS & $\mathrm{AVG}$ \\
\hline 1 & USA & 285 & 0.4241 & USA & 4358 & 15.291 \\
\hline 2 & England & 35 & 0.0521 & England & 332 & 9.486 \\
\hline 3 & China & 30 & 0.0446 & $\begin{array}{l}\text { United } \\
\text { Kingdom }\end{array}$ & 194 & 8.435 \\
\hline 4 & India & 25 & 0.0372 & Australia & 157 & 6.542 \\
\hline 5 & Australia & 24 & 0.0357 & Germany & 150 & 8.333 \\
\hline
\end{tabular}

Source: Prepared by the author (2019). Using the R software. 
Table 4 shows that for the extracted sample from Web of Science and Scopus bases: five journals are connected to the information systems literature, one is related to operational research, and two are from marketing. The h5-index is also presented in this table, which is an h-index for articles published within the last five complete years. According to Hirsch (2005), the h-index is an excellent example of citation metrics that evaluates the productivity and the impact of published works of an academic or a journal.

Table 4 - Most relevant sources - Second step for beginners (where to search)

\begin{tabular}{lcccc}
\hline & SOURCES & ARTICLES & h5-index & JCR(2018) \\
\hline 1 & Expert Systems With Applications & 17 & 92 & 3.768 \\
\hline 2 & Decision Support Systems & 14 & 70 & 3.565 \\
\hline 3 & European Journal Of Operational Research & 13 & 82 & 3.428 \\
\hline 4 & IBM Journal Of Research And & 10 & 25 & 0.962 \\
& $\begin{array}{l}\text { Development } \\
5\end{array}$ & 10 & 26 & 1.465 \\
\hline 6 & Computer Standards \& Interfaces & 10 & 53 & 4.516 \\
\hline 7 & $\begin{array}{c}\text { International Journal Of Information } \\
\text { Management }\end{array}$ & 10 & 8 & $\begin{array}{c}\text { no longer } \\
\text { publishe } \\
\text { Journal Of Direct Data And Digital } \\
\text { Marketing Practice }\end{array}$ \\
\hline 8 & Marketing Science & 10 & 40 & 2.794 \\
\hline
\end{tabular}

Source: Prepared by the author (2019). Using the R software.

Bibliometrix created Table 5 from a total of 12,941 references found in the extracted sample. Therefore, they are the most referenced articles by authors. Although all these papers were evaluated and perceived as potentially significant in the existing literature that tries to associate marketing and analytics, the work of Chen et al. (2012) should be highlighted. Their bibliometric review and the nomological network not only show the importance of BI\&A but also demonstrate the connections with different lines of research, including marketing. 
Table 5 - Most referred articles- First step for beginners

\section{Most Referenced Papers} Total

Chen, H., Chiang, R. H. L., \& Storey, V. C. (2012). Business Intelligence and Analytics : From Big Data To Big Impact. MIS Quarterly, 36(4), 1165-1188.

Bollen, J., Mao, H., \& Zeng, X. (2011). Twitter mood predicts the stock market. Journal of Computational Science, 2(1), 1-8. https://doi.org/10.1016/j.jocs.2010.12.007

Manyika, J., Chui, M., Brown, B., Bughin, J., Dobbs, R., Roxburgh, C., \& Byers, A. H. (2011). Big data: The next frontier for innovation, competition, and productivity. McKinsey Global Institute, (June), 156. https://doi.org/10.1080/01443610903114527

McAfee, A., \& Brynjolfsson, E. (2012). Big Data. The management revolution.

Harvard Business Review, 90(10), 61-68. https://doi.org/10.1007/s12599-013$\underline{0249-5}$

Antweiler, W., \& Frank, Z. M. (2004). Is All That Talk Just Noise? The

Information Content of Internet Stock Message Boards. Journal of Finance, 59(3), 1259-1294. https://doi.org/10.1017/CBO9781107415324.004

Source: Prepared by the author (2019). Using the R software.

Most of the papers are theoretical or do not use management usual quantitative methods. The articles presented in Table 5 are the primary source for those less familiar with the subject.

\section{Analytical step}

A Bibliometric work enables the combination of an enormous amount of bibliographic data through statistical analyses (Vogel \& Guttel, 2013). It was initiated a descriptiveanalytical step with author co-citation description after author coupling, and keywords cooccurrence were also described graphically. As an aesthetics option, it was decided not to show all cluster analyses in graphics. Author co-citation has a size (number of vertices) of 5945, and Chen $\mathrm{H}$. is the top overall author, centrality index (0.320), and betweenness index (0.064). These indexes highlighted the author adopted as the cornerstone work. Co-citation is reasonable to interpret the foundations; however, to find trends, it is necessary a coupling analysis (Vogel \& Güttel, 2013).

Coupling analysis is a bibliometric technique that measures the frequency in which two documents of a sample have at least one reference in common. Then it considers the overlap of their bibliographies (Kessler, 1963; Zupic \& Cater, 2015). The bibliographic 
coupling shifts attention from foundations to trends in scientific literature, enhancing bibliometric applications (Vogel \& Guttel, 2013). Figure 1 presents the bibliographic coupling for the present sample.

There are several centrality indexes used to measure the ways in which authors may be connected to one another. For a detailed comparison and its use in marketing, see Chandler and Wieland (2010). Briefly, the betweenness centrality was created by Freeman (1978), and it is the "least number of connections that pass through actor $\mathrm{k}$ and connect actor $\mathrm{i}$ and actor $\mathrm{j}$ together" (Chandler \& Wieland, 2010, p. 205), i.e., it is a measure of flow, meaning that the greater the index, the greater is the importance of the actor (an author, university or keyword) to the literature. For example, authors with higher index become connectors, and other authors may become dependent on them as bridges to other papers, not directly connected.

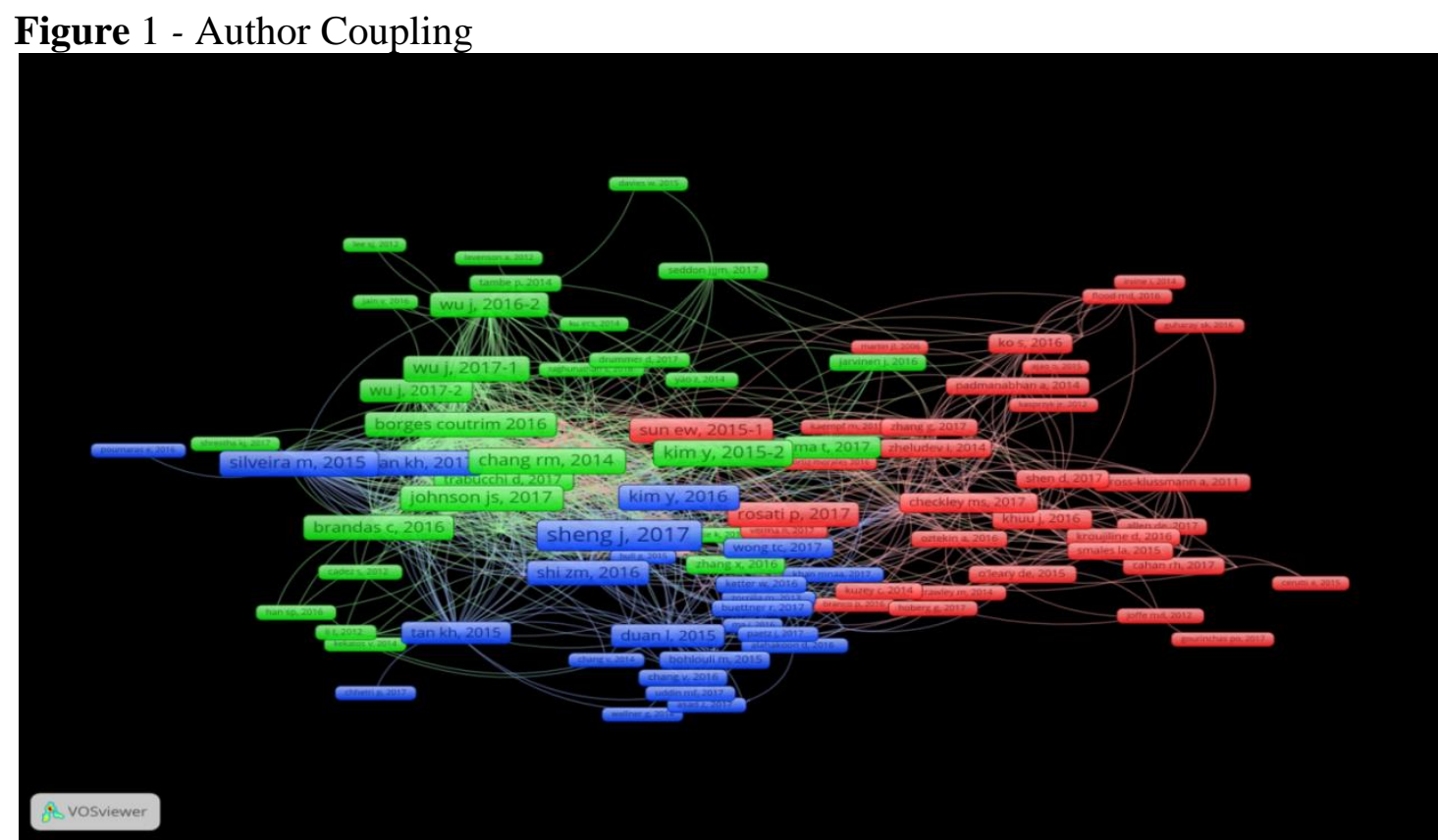

Source: Prepared by the author (2019). Using the R and VOSViewer software.

Table 6 presents a fractional counting of author coupling. When fractional counting is used, it reduces the influence of documents with many authors (Perianes-Rodriguez, Waltman, \& van Eck, 2016). 
Table 6 - Top betweenness centrality articles per cluster

\begin{tabular}{lll}
\hline Article & Cluster & $\begin{array}{l}\text { Betweenness } \\
\text { Centrality }\end{array}$ \\
\hline $\begin{array}{l}\text { Sheng, J., Amankwah-amoah, J., \& Wang, X. (2017). A multidisciplinary } \\
\text { perspective of big data in management research. International Journal of } \\
\begin{array}{l}\text { Production Economics, 191(November 2016), 97-112. } \\
\text { https://doi.org/10.1016/j.ijpe.2017.06.006 }\end{array}\end{array}$ & 386,98 \\
& &
\end{tabular}

Kumar, A., Bezawada, R., Rishika, R., Janakiraman, R., \& Kannan, P. K. $\quad$ Green $\quad$ 266,07 (2016). From social to sale: The effects of firm-generated content in social media on customer behavior. Journal of Marketing, 80(1), 7-25. https://doi.org/10.1509/jm.14.0249

Grover, P. (2017). Big Data Analytics : A Review on Theoretical Green 222,14 Contributions and Tools Used in Literature. Global Journal of Flexible Systems Management, 18(3), 203-229. https://doi.org/10.1007/s40171017-0159-3

Johnson, J. S., Friend, S. B., \& Lee, H. S. (2017). Big Data Facilitation, $\quad$ Green 217,52 Utilization, and Monetization: Exploring the $3 \mathrm{Vs}$ in a New Product Development Process. Journal of Product Innovation Management, 34(5), 640-658. https://doi.org/10.1111/jpim.12397

Tan, K. H., Zhan, Y. Z., Ji, G., Ye, F., \& Chang, C. (2015). Harvesting big Blue 216,23 data to enhance supply chain innovation capabilities: An analytic infrastructure based on deduction graph. International Journal of Production Economics, 165(July 2015), 223-233. https://doi.org/10.1016/j.ijpe.2014.12.034

Tan, K. H., \& Zhan, Y. (2017). Improving new product development using big data: a case study of an electronics company. $R$ and $D$ Management, 47(4), 570-582. https://doi.org/10.1111/radm.12242

Rosati, P., Cummins, M., Deeney, P., Gogolin, F., van der Werff, L., \& Red 159,57 Lynn, T. (2017). The effect of data breach announcements beyond the stock price: Empirical evidence on market activity. International Review of Financial Analysis, 49, 146-154. https://doi.org/10.1016/j.irfa.2017.01.001

Chou, C., Chang, C. J., \& Peng, J. (2016). Integrating XBRL data with Red 75,88 textual information in Chinese : A semantic web approach. International Journal of Accounting Information Systems, 21, 32-46. https://doi.org/10.1016/j.accinf.2016.04.002

Huang, T., Fildes, R., \& Soopramanien, D. (2014). The value of Red 70,09 competitive information in forecasting FMCG retail product sales and the variable selection problem. European Journal of Operational Research, 237(2), 738-748. https://doi.org/10.1016/j.ejor.2014.02.022

Source: Prepared by the author (2019). Using the R software. 
As can be seen in Table 6, the red cluster has smaller centrality indexes. Additionally, Figure 1 represents it as a separate, detached, literature from cluster blue and green. Indeed, the red cluster presents more technical papers, applications on marketing (Huang, Fildes, \& Soopramanien, 2014), finance (Rosati et al., 2017), or accounting (Chou, Chang, \& Peng, 2016). For example, Huang, Fildes, and Soopramanien (2014) discuss sales forecasting, but the focus is on the best algorithm choice, comparing time series and "autoregressive distributed lag." For their part, Chou, Chang, and Peng (2016) discuss semantic web technologies to integrate textual accounting disclosures.

On the other hand, with a more theoretical approach, the blue cluster discusses the application of big data in supporting supply chain operations (Tan, Zhan, Ji, Ye, \& Chang, 2015) and attempts to explain how organizations gain new product development ideas or optimize their manufacturing processes using big data. For their turn, Sheng, Amankwahamoah, and Wang (2017) created a big data bibliography review and generated a framework for value achievement and management practice. Finally, Tan and Zhan (2017) also discuss new product development on three electronics companies as successful case studies. Again, most of the papers are theoretical or do not use management frequent quantitative methods.

The green cluster is focused on marketing, and most of the papers are related to its issues, especially customer orientation. For example, Johnson, Friend, and Lee (2017) focus on new product development using big data by contrasting the exploration and exploitation of different market turbulences. Kumar et al. (2016) empirically tested customer performance using social media as a channel for marketing communication through inbound marketing. In addition, Grover (2017) also discusses competitive advantage and organizational performance. His focus is on the evolution of big data on social media analytics, text mining, and machine learning applications on marketing and supply chain management disciplines, considering a multi-industry overview of platforms and tools.

We also analyzed the conceptual structure of the field with another network analysis, evaluating the clusters of keywords co-occurrence. This method uses the actual content of the documents to build a similarity measure (Callon, Courtial, Turner, \& Bauin, 1983).

Figure 2 shows almost all vertices or keywords available. It is a square matrix initially created with a 1,909 dimension of the keywords, also called similarity matrix, which results in the proximity rates that are plotted in a map using the free software VOSViewer (van Eck \& Waltman, 2010). In both Figures 1 and 2, it was adopted probabilistic similarity measures for normalization purposes. The probabilistic method name in VosViewer is "Association 
strength," understood as the best normalization for scientometric research (Eck \& Waltman, 2009).

Figure 2 - Keywords Co-occurrence

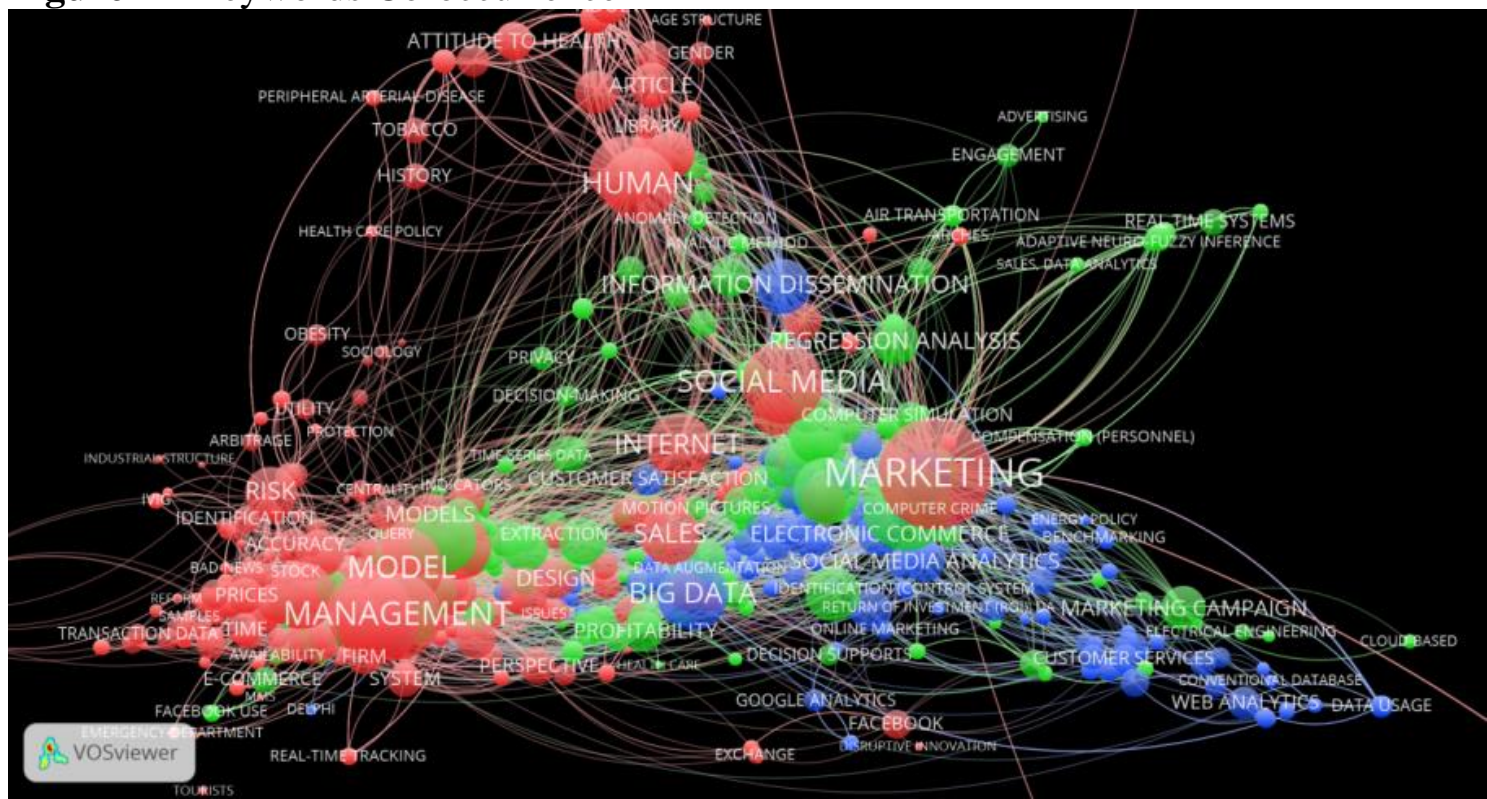

Source: Prepared by the author (2019). Using the R and VOSViewer software.

The red cluster was categorized as "Performance Management," with a total of 911 keywords, which are mostly related to management/strategy literature. Then the blue cluster was categorized as "Technology and Learning." It has 405 keywords, and more technical or information systems literature related. Lastly, the green cluster was categorized as "Customer Orientation," with 653 keywords, and it is more related to marketing. The most important keywords are referenced by the clusters in Table 7 . 
Table 7 - Top betweenness centrality keywords per cluster

\begin{tabular}{lll}
\hline Keyword & Cluster & $\begin{array}{l}\text { Betweenness } \\
\text { Centrality }\end{array}$ \\
\hline Marketing & Red & 248,17 \\
\hline Sales & Red & 84,86 \\
\hline Management & Red & 56,40 \\
\hline Social media & Blue & 51,41 \\
\hline Data mining & Blue & 34,50 \\
\hline Learning systems & Blue & 14,87 \\
\hline Big data & Blue & 14,12 \\
\hline Decision making & Green & 12,68 \\
\hline Artificial intelligence & Blue & 10,84 \\
& & \\
\hline Forecasting & Red & 9,55 \\
\hline Model & Red & 9,47 \\
\hline Profitability & Green & 7,62 \\
\hline Algorithms & Blue & 7,22 \\
\hline Internet & 6,77 \\
\hline Electronic commerce & Green & 6,72 \\
\hline Source: Prepared by the author (2019). Using the R software. \\
\hline
\end{tabular}

We used the bibliometric analytical step as a start to understanding the primary constructs for an additional step that deepens the literature review belonging to capabilities in marketing, information systems, and strategy journals. The result of this revision focused on quantitative works pointed out as applied research. 


\section{Applied research review: trends}

Because most of the papers are theoretical or do not use frequent management quantitative methods, it was also performed an applied bibliographical revision (Table 8) in international journals with significant JCR indexes, deliberated as more than one, and available in periodicos.capes.gov.br. The searched constructs were related to "Performance Management," "Technology and Learning," or "Customer Orientation."

For this applied bibliographical revision, we followed Hong, Chan, Thong, Chasalow, and Dhillon (2013) guidelines, about contextual constructs, i.e., similar constructs with different names depending on context, the present work considered terms like big data analytics, social media analytics, marketing analytics, and customer analytics as constructs related to specific contexts from the general construct business analytics, following the Chen et al. (2012) approach. It was necessary to analyze quantitative works using all these terms.

By delimitation, it was included only the papers that exhibited the structural model and their respective measurements. Other works, not initially selected, were included by ramification, like a snowball (similar to convenience sampling) from the articles initially chosen. The result is presented in Table 8, which is the summary of this applied bibliographic review with pertinent and explicit quantitative models only. It shows the constructs and a brief description of the general idea of each work.

Table 8 reveals a list of selected applied research with explicit quantitative models since the year 2010, from where future studies can be operationalized using the nomological network constructs options (see Figure 4). Marketing analytics can be studied from the capabilities literature point of view (Germann et al., 2014; Wamba et al., 2017), but a literature mapping shows different levels of abstractions and some challenging issues (see Figure 3). Figure 3 helps to explain the present work's theoretical background/choices. 
Table 8 - Applied studies summary

\begin{tabular}{lll}
\hline Reference & Constructs & Main Results \\
\hline (Chang et & 1.1Customer-centric organizational culture \\
al., 2010) & 1.2Customer-centric management system & $\begin{array}{l}\text { Marketing Capability is the } \\
\text { mediator between CRM use and } \\
\text { 2.CRM technology use } \\
\text { 3.Marketing capabilities } \\
\text { 4.Organizational performance }\end{array}$ \\
\hline $\begin{array}{l}\text { (Trainor et } \\
\text { al., 2014) }\end{array}$ & 1.1Customer-Centric Management System & The usage of social media \\
& 2-Social CRM capabilities & technology does not by itself \\
3-Customer Relationship performance & development of relationship \\
Covariate(Cov)1-Training & performance. \\
Cov2-Management Support &
\end{tabular}

Cov3-Organizational Size

(Wamba et 1.1-BDA(big data analytics) infrastructure Direct impact from the Big Data al., 2017) capability

Analytics Capability in

1.2-BDA management capability

performance, just as the

1.3- BDA personnel capability

mediating effects of "Process

2- BDA capability

3-process-oriented dynamic capabilities Orientation Capability" over this 4-Performance

(Côrte- 1.1-endogenous knowledge management $\quad$ To create agility, external

Real et al., 1.2-exogenous knowledge management knowledge from Big Data

2017) 1.3-knowledge sharing with partners Analytics applications can be 2-Agility more effective than internal

3-Process-level performance knowledge.

4-competitive advantages

cov1- "time since adoption of BDA"; cov2-

industry; cov3-country; cov4-technological

turbulence; cov5 -Leadership in

product/process innovation; cov6- Impact of new technology on operations.

(Chuang \& 1.1- e-service capability

Lin, 2017) 1.2 - service innovation orientation

2- information-value offering

3- Customer relationship performance

4-Organizational performance

cov- market turbulence

(Popovič, 1-Information sharing values (ISV)

Hackney, 2.1-BI system quality (BISQ)

Coelho, \& 2.2 -Information quality (IQ)

Jaklič, 3-Information use (IU)

2014)

(Chuang \& 1-Technology resource

Lin, 2013) 2-Human resource

3-Business resource

4-Customer orientation

5-Customer information quality

6-Customer relationship performance

7-Overall firm performance

The positive effects of the information value in customer relationship performance and Organizational performance became evident in highly turbulent markets.

The information-sharing value is a mediator between the dimensions of information systems.

The customer relationship performance has a mediating role in the relation between the quality of the customer's information and the global performance of the organization.

Source: Prepared by the author (2019). 
Figure 3 shows, on the left side, the levels of abstractions found in marketing and strategy literature about capabilities. It means that it is possible to talk about capabilities general level and 3 levels of marketing capabilities, according to Day (2011, 2014). And the right side interconnects the three literature the present work uses.

Figure 3 - Literature levels of abstractions
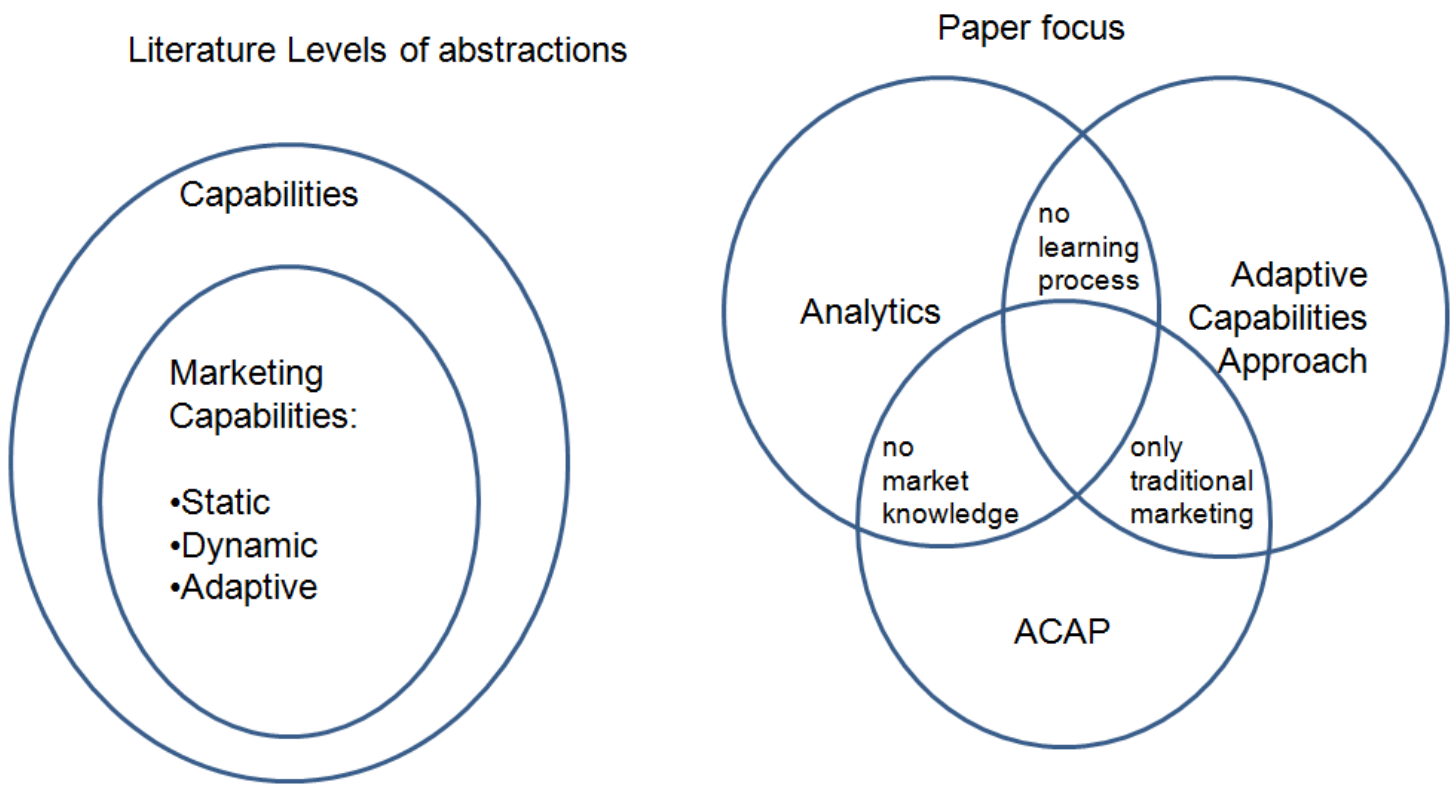

Source: Prepared by the authors (2019).

On the right side, the intersections represent research opportunities or issues. Issue 1 (no market knowledge) of Figure 3 is related to how information systems literature uses capabilities to explain the learning process, but these approaches don't focus on the market knowledge learning (Teo, Nishant, \& Koh, 2016; Wang \& Byrd, 2017), and market knowledge is vital for changing organizational strategies (Barrales-Molina et al., 2014).

Issue 2 (only traditional marketing) of Figure 3 is related to how marketing and strategy literature uses the absorptive capacity (ACAP) concept of the learning process. It uses exploitative and explorative processes or responsive and proactive market orientation (Barrales-Molina et al., 2014; Ozdemir, Kandemir, \& Eng, 2017).This literature is prominent, but it lacks discussing analytics; thus, it stays in traditional marketing methods (Wedel \& Kannan, 2016); it doesn't narrow the marketing capabilities gap.

Disciplines of marketing (Germann et al., 2014; Wang \& Hajli, 2017) and information systems (Pavlou \& Sawy, 2010; Teo et al., 2016) are interested in the market knowledge 
exploitative and explorative learning process. However, Day (2011) proposed anticipatory and experimental dimensions to close the marketing gap, and the Issue 3 (no learning process) of Figure 3 gives this opportunity of explaining the Day approach using analytics, but still last one question about the learning process that has its response in the intersection of the three literature.

In summary, we propose a construct, adaptive analytics capabilities, as the full intersection of Figure 3.

\section{Nomological network: trends}

Figure 4 proposes adaptive analytics capabilities as the main exogenous construct of the nomological network developed from applied review.

Figure 4 - Nomological network

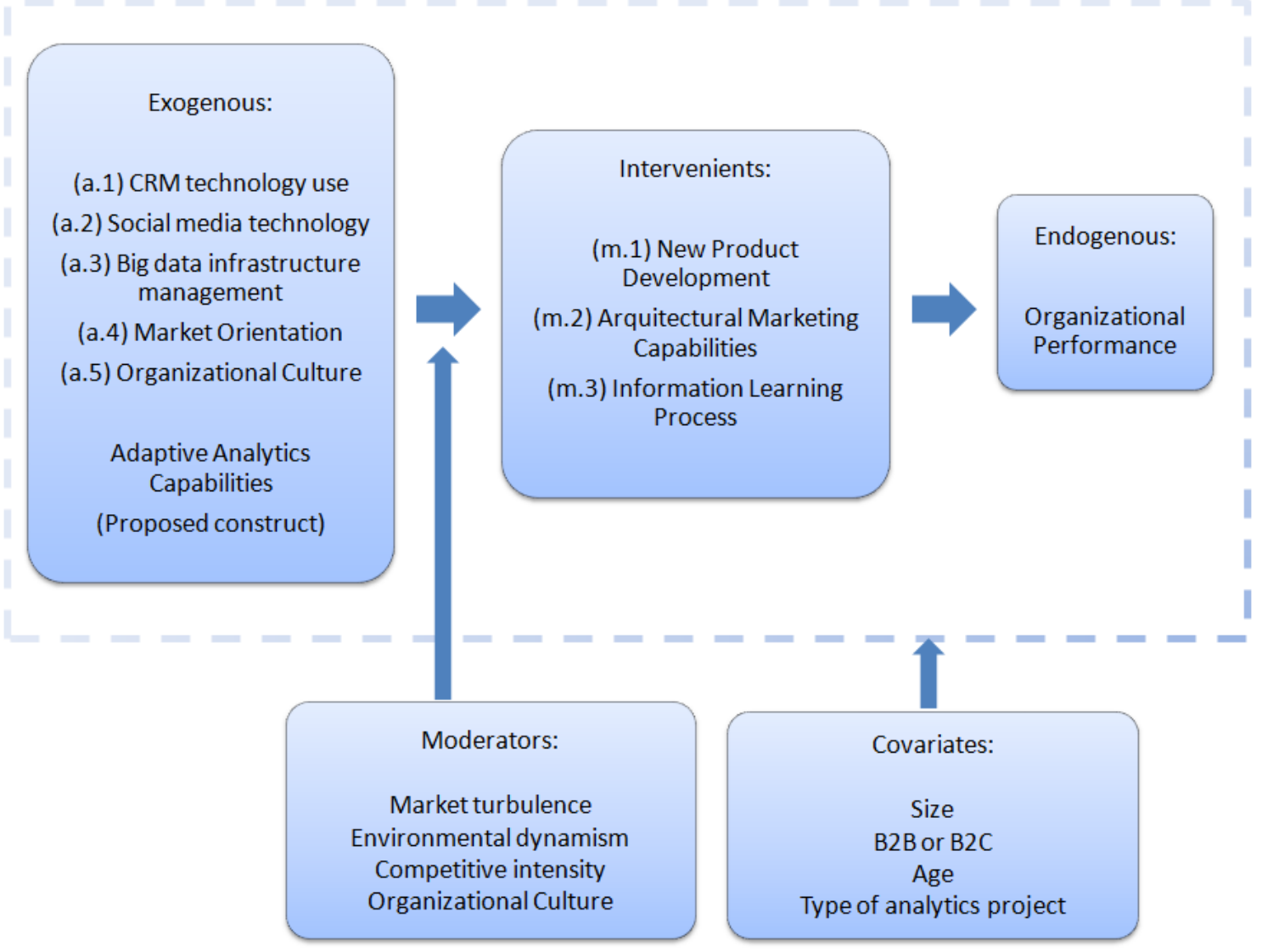

Source: Prepared by the author (2019).

Figure 4 shows suggested exogenous, covariates, intervenients, and endogenous from the systematic review. Some possible reference papers for concurrent exogenous constructs 
are (a.1) (Chang et al., 2010), (a.2): (Trainor et al., 2014), (a.3) (Wamba et al., 2017), (a.4) (Rapp et al., 2010) and (a.5)(Chang et al., 2010; Trainor et al., 2014). The covariates, moderators, and performance are from recurrent sources of the literature (Jayachandran, Sharma, Kaufman, \& Raman, 2005; Rapp el al., 2010). Finally, the intervenients/mediation reference works are (m.1) (Xu et al., 2016), (m.2) (Morgan, Zou, Vorhies, \& Katsikeas, 2003), and (m.3) (Cohen \& Levinthal, 1990).

\section{Discussions}

We analyzed the clusters in Figures 1 and 2, and Tables 7 and 8; firstly, it was seen that the "Consumer Orientation" cluster seems to be a central topic in the intersection between marketing and analytics. This cluster mostly involves analyzing structured data or text, social media, mobile data, etc., for marketing and operation purposes. Consumer feelings and behavior are hard to grasp due to market/customer turbulence (Johnson, Friend, \& Lee, 2017), but it is on the focus of social analysts, especially in marketing. This cluster presents most of the exogenous constructs of Figure 4.

Secondly, in the "Performance Management" cluster, big data is hyped (Grover, 2017; Tan, Zhan, Ji, Ye, \& Chang, 2015). New approaches in marketing analytics attempt to improve organizational performance (Kim, Jo, \& Shin, 2016). Many papers predict big data's impact on organizational performance, and its changes in management and strategy are also discussed (Sheng, Amankwah-amoah, \& Wang, 2017). This cluster presents different flavors of the endogenous construct of Figure 4.

Thirdly, "Technology and Learning" cluster papers usually deals with analytics/data science techniques and technological issues. These technologies improve information collection and market data processing to predict, for example, customer behavior/feelings (Kumar et al., 2016). The main objective of some of these papers is to enhance operational efficiency using analytics and capabilities (Popovič, Hackney, Tassabehji, \& Castelli, 2016; Chen \& Nath, 2018). This cluster presents most of the mediators and moderators constructs of Figure 4.

A recurrent and vital step to develop a model is the construct choice process (MacKenzie, Podsakoff, \& Podsakoff, 2011), and a nomological network can help with this (see Figure 4). This step is especially crucial for marketing latent constructs (Jarvis, MacKenzie, \& Podsakoff, 2004). Thus, after the systematic review of quantitative papers, Figure 4 proposed an initial nomological network. Before that, Figure 3 presented the 
issues/gaps in the literature and offered adaptive analytics capabilities as an answer that covers these issues.

Adaptive analytics capabilities were engendered after reading the papers separated by author coupling analysis. We inferred that green and blue clusters are mostly related to business, management, and marketing papers. The green cluster can be connected with "Customer Orientation," the blue with "Performance Management," and the red cluster can be linked to "Technology and Learning," representing a more computational or technological group of papers. Thus, adaptive analytics capabilities try to connect these three clusters.

Adaptive analytics capabilities can represent a learning process that is concerned with the market knowledge and overcomes traditional marketing methods using analytics. The nomological network is helpful in developing future models, aiming to embrace adaptive analytics capabilities, its relationship with organizational performance, and also presents the most critical candidate variables in the context for moderation and mediation analyses.

\section{Conclusions}

The present work serves as a guide for the study of the emerging area of analytics in marketing using capabilities literature. Similar to Chen et al. (2012), a bibliometric study was carried out to raise state of the art on academic discussions surrounding BI\&A, and, then, to combine it with RBV/capabilities related publications. It works as the basis for a better comprehension of the phenomenon by beginners (as seen in Tables 4 and 5) and a shortcut for advanced researchers (see information in Table 8 and Figure 4). With this, we answered the research question RQ1.

In addition to the bibliometric examination, an applied review was conducted to identify research opportunities and issues (RQ2) and to generate a nomological network (RQ3) after reading all sample abstracts and all papers content from Tables 5, 6, and 8. As well as to report the operationalized, most used, and theory consistent variables related to the phenomenon, together with possible covariates and other intervening variables. Thus, the major contribution of the present work is to provide theoretical model options using past research to ease future quantitative studies about the intersection between marketing and analytics.

"Consumer Orientation," Technology and Learning," and "Performance Management" are the trending areas. Additionally, the review shows that the technologies which ease direct interactions between organizations and customers can boost products and services 
offers/development. Therefore, consumer orientation is hyped by using analytics as a new core element for marketing strategy. In this context, big data is even more hyped (Johnson, Friend, \& Lee, 2017). The literature also presents solutions such as more specialized market segmentation/personalization, advancing the brand, and advertising research (Kumar et al., 2016). These trends make the research agenda.

An opportunity comes from testing some of the possible relationships of the nomological network (see Figure 4). Future studies could focus on the impacts of the adaptive mechanisms upheld by analytics. Exogenous constructs from the nomological network can be seen as path-dependence elements, and, then, can be studied using a longitudinal approach to understand the building process of these paths with any other moderator, mediator, or covariate presented. Industry idiosyncrasies can tell the story of capabilities path-dependence elements.

New quantitative work can follow the idea of some current studies that provided empirical evidence confirming the role developed by organizational capabilities to generate dynamism from their innovation/technology team (Barrales-Molina et al., 2014). The quantitative work can study sustained/durable or temporary/transient (Day, 2014) competitive advantages. In any of these scenarios, it is proposed that future studies include constructs related to technology, such as team capability, technology use, technology infrastructure, technology management/leadership, and/or innovation orientation.

This paper suggests performance as a primary endogenous construct. Admittedly, it is possible to deal with customer relationships, marketing, financial, or other types of performance, with subjective or objective approaches. On the other hand, there are many endogenous possibilities, and we suggest a few in the nomological network.

The covariates showed in Figure 4 encourage research about performance and its antecedents, and also, moderation and/or mediation and/or covariates typical of common constructs, like training, management support, size, industry, country, and/or more exciting constructs, such as environmental dynamism, leadership in innovation, culture, the impact of new technology, market or technological turbulence. For sure, this is not the whole list, but it presents thousands of possibilities to explain performance in different contexts.

From this myriad of modeling possibilities, there is one exciting issue not discussed in the present paper and shown in the nomological network (see Figure 4): How organizational culture is inserted in the model? As an exogenous construct, as a moderator or as part of adaptive analytics construct? 


\section{References}

Aria, M., \& Cuccurullo, C. (2017).bibliometrix: An R-tool for comprehensive science mapping analysis. Journal of Informetrics, 11(4), 959-975.

https://doi.org/10.1016/j.joi.2017.08.007.

Barney, J. B. (2014). How marketing scholars might help address issues in resource-based theory. Journal of the Academy of Marketing Science, 42(1), 24-26. https://doi.org/10.1007/s11747-013-0351-8.

Barrales-Molina, V., Martínez-López, F. J., \& Gázquez-Abad, J. C. (2014). Dynamic marketing capabilities: Toward an integrative framework. International Journal of Management Reviews, 16(4), 397-416. https://doi.org/10.1111/ijmr.12026.

Braganza, A., Brooks, L., Nepelski, D., Ali, M., \& Moro, R. (2017). Resource management in big data initiatives: Processes and dynamic capabilities. Journal of Business Research, 70, 328-337. https://doi.org/10.1016/j.jbusres.2016.08.006.

Callon, M., Courtial, J. P., Turner, W. A., \& Bauin, S. (1983). From translations to problematic networks: An introduction to co-word analysis. Social Science Information, 22(2), 191-235. https://doi.org/10.1177/053901883022002003.

Chandler, J. D., \& Wieland, H. (2010). Embedded Relationships: Implications for Networks, Innovation, and Ecosystems. Journal of Business Market Management, 4(4), 199-215. https://doi.org/10.1007/s12087-010-0041-5.

Chang, W., Park, J. E., \& Chaiy, S. (2010). How does CRM technology transform into organizational performance? A mediating role of marketing capability. Journal of Business Research, 63(8), 849-855. https://doi.org/10.1016/j.jbusres.2009.07.003.

Chen, L., \& Nath, R. (2018). Business analytics maturity of firms: an examination of the relationships between managerial perception of IT, business analytics maturity and success. Information Systems Management, 35(1), 62-77.

https://doi.org/10.1080/10580530.2017.1416948.

Chen, H., Chiang, R. H. L., \& Storey, V. C. (2012). Business Intelligence and Analytics : From Big Data To Big Impact. MIS Quarterly, 36(4), 1165-1188.

Chou, C., Chang, C. J., \& Peng, J. (2016).Integrating XBRL data with textual information in Chinese : A semantic web approach. International Journal of Accounting Information Systems, 21, 32-46. https://doi.org/10.1016/j.accinf.2016.04.002.

Chuang, S.-H., \& Lin, H.-N. (2013). The roles of infrastructure capability and customer orientation in enhancing customer-information quality in CRM systems: Empirical evidence from Taiwan. International Journal of Information Management, 33(2), 271-281. https://doi.org/10.1016/j.ijinfomgt.2012.12.003.

Chuang, S. H., \& Lin, H. N. (2017). Performance implications of information-value offering in e-service systems: Examining the resource-based perspective and innovation strategy. 
Journal of Strategic Information Systems, 26(1), 22-38.

https://doi.org/10.1016/j.jsis.2016.09.001.

Cohen, W. M., \& Levinthal, D. A. (1990). Absorptive Capacity : A New Perspective on Learning and Innovation. Administrative Science Quarterly, 35(1), 128-152. https://doi.org/10.2307/2393553.

Conti, C. R., Parente, R., \& de Vasconcelos, F. C. (2015).When distance does not matter: Implications for Latin American multinationals. Journal of Business Research, 69(6), 1980-1992. https://doi.org/10.1016/j.jbusres.2015.10.144.

Cooke, A. D. J., \& Zubcsek, P. P. (2017). The Connected Consumer: Connected Devices and the Evolution of Customer Intelligence. Journal of the Association for Consumer Research, 2(2).

Côrte-Real, N., Oliveira, T., \& Ruivo, P. (2017).Assessing business value of Big Data Analytics in European firms. Journal of Business Research, 70, 379-390. https://doi.org/10.1016/j.jbusres.2016.08.011.

Day, G. S. (2011).Closing the Marketing Capabilities Gap. Journal of Marketing, 75(4), 183195. https://doi.org/10.1509/jmkg.75.4.183

Day, G. S. (2014).An outside-in approach to resource-based theories. Journal of the Academy of Marketing Science, 42(1), 27-28. https://doi.org/10.1007/s11747-013-0348-3.

Freeman, L. C. (1978). Centrality in Social Networks Conceptual Clarification. Social Networks, 1, 215-239.

Germann, F., Lilien, G. L., Fiedler, L., \& Kraus, M. (2014). Do Retailers Benefit from Deploying Customer Analytics? Journal of Retailing, 90(4), 587-593.

https://doi.org/10.1016/j.jretai.2014.08.002.

Grover, P. (2017). Big Data Analytics : A Review on Theoretical Contributions and Tools Used in Literature. Global Journal of Flexible Systems Management, 18(3), 203-229. https://doi.org/10.1007/s40171-017-0159-3.

Hirsch, J. E. (2005). An index to quantify an individual's scientific research output. Proceedings of the National Academy of Sciences of the United States of America, 102(46), 16569-16572. https://doi.org/10.1073/pnas.0507655102.

Hong, W., Chan, F. K. Y., Thong, J. Y. L., Chasalow, L. C., \& Dhillon, G. (2013). A Framework and Guidelines for Context-Specific Theorizing in Information Systems Research. Information Systems Research, 7047(2004), 1-26.

Jarvis, C. B., MacKenzie, S. B., \& Podsakoff, P. M. (2004).A Critical Review of Construct Indicators and Measurement Model Misspecification in Marketing and Consumer Research. Journal of Consumer Research, 30(September 2003), 199-218. https://doi.org/10.1086/376806. 
Jayachandran, S., Sharma, S., Kaufman, P., \& Raman, P. (2005).The role of relational information processes and technology use in customer relationship management. Journal of Marketing, 69(4), 177-192. https://doi.org/10.1509/jmkg.2005.69.4.177.

Johnson, J. S., Friend, S. B., \& Lee, H. S. (2017). Big Data Facilitation, Utilization, and Monetization: Exploring the 3Vs in a New Product Development Process. Journal of Product Innovation Management, 34(5), 640-658. https://doi.org/10.1111/jpim.12397.

Kessler, M. M. (1963). Bibliographic Coupling Between Scientific Papers. American Documentation, 14(1), 10-25.

Khanagha, S., Volberda, H., \& Oshri, I. (2017). Customer Co-Creation and Exploration of Emerging Technologies: The Mediating Role of Managerial Attention and Initiatives. Long Range Planning, 50, 221-242. https://doi.org/10.1016/j.lrp.2015.12.019.

Kim, H. J., Jo, N. O., \& Shin, K. S. (2016). Optimization of cluster-based evolutionary undersampling for the artificial neural networks in corporate bankruptcy prediction. Expert Systems with Applications, 59, 226-234. https://doi.org/10.1016/j.eswa.2016.04.027.

Kumar, A., Bezawada, R., Rishika, R., Janakiraman, R., \& Kannan, P. K. (2016). From social to sale: The effects of firm-generated content in social media on customer behavior. Journal of Marketing, 80(1), 7-25. https://doi.org/10.1509/jm.14.0249.

MacKenzie, Podsakoff, \& Podsakoff. (2011). Construct Measurement and Validation Procedures in MIS and Behavioral Research: Integrating New and Existing Techniques. MIS Quarterly, 35(2), 293. https://doi.org/10.2307/23044045.

MacRoberts, M. H., \& MacRoberts, B. R. (2010). Problems of citation analysis: A study of uncited and seldom-cited influences. Journal of the American Society for Information Science and Technology, 61(1), 1-12. https://doi.org/10.1002/asi.21228.

Morgan, N. A., Zou, S., Vorhies, D. W., \& Katsikeas, C. S. (2003). Experiential and Informational Knowledge, Architectural Marketing Capabilities, and the Adaptive Performance of Export Ventures: A Cross-National Study. Decision Sciences, 34(2), 287321. https://doi.org/10.1111/1540-5915.02375.

Ozdemir, S., Kandemir, D., \& Eng, T. (2017). The role of horizontal and vertical new product alliances in responsive and proactive market orientations and performance of industrial manufacturing firms. Industrial Marketing Management, 64(July), 25-35. https://doi.org/10.1016/j.indmarman.2017.03.006

Pavlou, P. A., \& Sawy, O. A. E. (2010). The "third hand": IT-enabled competitive advantage in turbulence through improvisational capabilities. Information Systems Research, 21(3), 443-471. https://doi.org/10.1287/isre.1100.0280.

Popovič, A., Hackney, R., Coelho, P. S., \& Jaklič, J. (2014). How information-sharing values influence the use of information systems: An investigation in the business intelligence systems context. The Journal of Strategic Information Systems, 23, 270-283. https://doi.org/10.1016/j.jsis.2014.08.003. 
Popovič, A., Hackney, R., Tassabehji, R., \& Castelli, M. (2016). The impact of big data analytics on firms ' high value business performance. Information Systems Frontiers, 20(2), 209-222. https://doi.org/10.1007/s10796-016-9720-4.

Quevedo-Silva, F., Santos, E. B. A., Brandão, M. M., \& Vils, L. (2016). ESTUDO BIBLIOMÉTRICO: ORIENTAÇÕES SOBRE SUA APLICAÇÃO. Revista Brasileira de Marketing, 15(2), 246-262. https://doi.org/10.5585/remark.v15i2.3274.

R Core Team (2019). R: A language and environment for statistical computing. R Foundation for Statistical Computing, Vienna, Austria.URL https://www.R-project.org/.

Rapp, A., Trainor, K. J., \& Agnihotri, R. (2010). Performance implications of customerlinking capabilities: Examining the complementary role of customer orientation and CRM technology. Journal of Business Research, 63(11), 1229-1236.

https://doi.org/10.1016/j.jbusres.2009.11.002

Rosati, P., Cummins, M., Deeney, P., Gogolin, F., van der Werff, L., \& Lynn, T. (2017). The effect of data breach announcements beyond the stock price: Empirical evidence on market activity. International Review of Financial Analysis, 49, 146-154. https://doi.org/10.1016/j.irfa.2017.01.001.

Sheng, J., Amankwah-amoah, J., \& Wang, X. (2017).A multidisciplinary perspective of big data in management research. International Journal of Production Economics, 191(November 2016), 97-112. https://doi.org/10.1016/j.ijpe.2017.06.006.

Tan, K. H., \& Zhan, Y. (2017). Improving new product development using big data: a case study of an electronics company. $R$ and D Management, 47(4), 570-582. https://doi.org/10.1111/radm.12242.

Tan, K. H., Zhan, Y. Z., Ji, G., Ye, F., \& Chang, C. (2015). Harvesting big data to enhance supply chain innovation capabilities: An analytic infrastructure based on deduction graph. International Journal of Production Economics, 165(July 2015), 223-233. https://doi.org/10.1016/j.ijpe.2014.12.034.

Teo, T. S. H., Nishant, R., \& Koh, P. B. L. (2016). Do shareholders favor business analytics announcements? Journal of Strategic Information Systems, 25(4), 259-276. https://doi.org/10.1016/j.jsis.2016.05.001.

Trainor, K. J., Andzulis, J., Rapp, A., \& Agnihotri, R. (2014). Social media technology usage and customer relationship performance: A capabilities-based examination of social CRM. Journal of Business Research, 67(6), 1201-1208. https://doi.org/10.1016/j.jbusres.2013.05.002.

Van Eck, N. J., \& Waltman, L. (2010). Software survey: VOSviewer, a computer program for bibliometric mapping. Scientometrics, 84(2), 523-538. https://doi.org/10.1007/s11192-0090146-3.

Vogel, R., \& Güttel, W. H. (2013). The dynamic capability view in strategic management: A bibliometric review. International Journal of Management Reviews, 15(4), 426-446. https://doi.org/10.1111/ijmr.12000. 
Wamba, S. F., Gunasekaran, A., Akter, S., Ren, S. J., Dubey, R., \& Childe, S. J. (2017). Big data analytics and firm performance: Effects of dynamic capabilities. Journal of Business Research, 70, 356-365. https://doi.org/10.1016/j.jbusres.2016.08.009.

Wang, Y., \& Byrd, T. A. (2017).Business analytics-enabled decision-making effectiveness through knowledge absorptive capacity in health care. Journal of Knowledge Management, 21(3), 517-539. https://doi.org/10.1108/JKM-08-2015-0301

Wang, Y., \& Hajli, N. (2017).Exploring the path to big data analytics success in healthcare. Journal of Business Research, 70, 287-299. https://doi.org/10.1016/j.jbusres.2016.08.002

Wedel, M., \& Kannan, P. K. (2016). Marketing Analytics for Data-Rich Environments. Journal of Marketing, 80(6), 97-121. https://doi.org/10.1509/jm.15.0413

Xu, Z., Frankwick, G. L., \& Ramirez, E. (2016). Effects of big data analytics and traditional marketing analytics on new product success: A knowledge fusion perspective. Journal of Business Research, 69(5), 1562-1566. https://doi.org/10.1016/j.jbusres.2015.10.017 


\title{
FUNDAÇÕES E TENDÊNCIAS NO RELACIONAMENTO ENTRE ANALYTICS E MARKETING
}

\author{
Alamir Costa Louro \\ Doutorado em Administração de Empresas \\ Universidade Federal do Espírito Santo - UFES. \\ Vitória, ES- Brasil. \\ alamirlouro@gmail.com \\ iD Marcelo Moll Brandão \\ Doutorado em Administração de Empresas \\ Universidade Federal do Espírito Santo - UFES. \\ Vitória, ES- Brasil. \\ Mollmkt@gmail.com \\ Arthur França Sarcinelli \\ Mestre em Administração de Empresas \\ Universidade Federal do Espírito Santo - UFES. \\ Vitória, ES- Brasil. \\ thearthursarcinelli@gmail.com
}

Objetivo: O propósito do presente artigo é pavimentar o caminho de futuras pesquisas quantitativas no campo de analytics em marketing, contextualizado com base na Visão Baseada em Recursos e na literatura sobre Capabilidades Dinâmicas.

Método/Abordagem: Constitui-se como uma revisão aplicada de cunho bibliométrico sobre o relacionamento entre as subáreas. Utilizamos análises de cluster para prover um mapeamento esquemático da interseção dessas literaturas para pesquisadores iniciantes e experientes.

Resultados: Após propor as capabilidades analíticas adaptativas, são sugeridos caminhos de avanço científico nas literaturas de marketing e estratégia, indicando possíveis construtos endógenos, exógenos e covariáveis para uma agenda de pesquisa voltada para situações de moderação e mediação.

Implicações teóricas e metodológicas: Foi construída uma rede nomológica que interliga o relacionamento emergente entre marketing, analytics e capabilidades dinâmicas que auxilia na escolha de construtos atualizados e relevantes para estudos quantitativos futuros.

Originalidade/valor: Destaca-se o alicerce da relação entre analytics e marketing, e assim são elucidadas as tendências de pesquisa e construtos objetivos otimizados para realização de pesquisas futuras sob a ótica das capabilidades dinâmicas.

Palavras-chave: Bibliometria. Analytics. Marketing. Capabilidades Dinâmicas.

\section{Como citar}

American Psychological Association (APA)

Brandão, M. M., Louro, A. C., \& Sarcinelli, A. F. (2021, jan./mar.). Fundações e tendências no relacionamento entre analytics e marketing. Revista Brasileira de Marketing - ReMarK, 20(1), 1-26. https://doi.org/10.5585/remark.v20i1.17554. 


\section{Introdução}

As particulariedades da dinâmica do mercado (Conti, Parente e Vasconcelos, 2015) alteram o dinamismo ambiental e a busca de vantagens competitivas.

A análise avançada com ênfase em marketing, denominada no presente trabalho como marketing analytics, ajuda a transformar dados internos ou externos em informações estratégicas, independente do seu grau de estruturamento. Ela exige algumas técnicas de modelagem de marketing em profundidade para a predição de respostas do mercado, para otimização do composto mercadológico e personalização para clientes (Wedel \& Kannan, 2016). A mineração de dados em textos, voz, vídeo, mídia digital ou sites é uma tecnologia que ajuda as organizações, fornecendo informações usadas para ajustar as regras de negócios e criar relacionamentos com os clientes de maneira mais relevante e conectada (Cooke \& Zubcsek, 2017).

O analytics vem ganhando força como campo de estudo nas últimas duas décadas, tanto no mundo dos negócios quanto na academia (Chen, Chiang \& Storey, 2012). Uma busca atual na ferramenta de pesquisa Google Scholar trouxe mais de 470 mil publicações relativas as palavras-chave "marketing" e "analytics".

Determinadas literaturas atualizadas já preveem, para algumas indústrias, que o analytics e algumas tecnologias emergentes serão facilitadoras de vantagem competitiva, de forma que as organizações precisam entender seus dados e prepará-los para um uso mais eficiente (Côrte-real, Oliveira, \& Ruivo, 2017; Wang; \& Hajli, 2017; Braganza, Brooks, Nepelski, Ali \& Moro, 2017).

O desenvolvimento de novos produtos (Xu, Frankwick e Ramirez, 2016), o feedback instantâneo e recorrente a partir das transações feitas pelos clientes (Cooke \& Zubcsek, 2017), além de insights compartilhados ou inovação por co-criação com clientes (Khanagha, Volberda e Oshri , 2017) são exemplos de atividades suportadas por tecnologias do analytics. Também existem exemplos em precificação e promoção, mix de marketing, valor do ciclo de vida do cliente (Germann, Lilien, Fiedler e Kraus, 2014), propaganda, força de vendas, marca, posicionamento e segmentação de mercado, todos orientados por dados (Wedel \& Kannan, 2016). A partir disso, podemos ver que o uso de analytics e suas tecnologias em marketing atraiu o foco de muitas pesquisas ao longo dos anos, porém nota-se uma falta de entendimento completo de como as capabilidades podem associar o analytics e o marketing ao desempenho organizacional. Portanto, o objetivo deste estudo é pavimentar o caminho para futuras pesquisas quantitativas no campo do analytics em marketing com base na literatura de 
capabilidades, sugerindo uma rede nomológica. Para isso, o artigo aborda as seguintes questões de pesquisa:

RQ1. Como o conhecimento básico na interseção entre marketing e analytics evoluiu com o tempo e quais são os principais tópicos e tendências hoje?

RQ2. Quais são as principais oportunidades ou problemas de pesquisa quando se trata de capabilidades de marketing?

RQ3. Quais são os potenciais construtos exógenos, covariáveis, intervenientes e endógenos para estudar o impacto das capabilidades analíticas adaptativas (construto proposto) no desempenho organizacional?

O presente trabalho e dividido em três partes: a primeira apresenta o desenvolvimento da pesquisa sobre analytics, com foco em seu uso em marketing; a segunda elucida os resultados bibliométricos e a revisão sistemática de artigos quantitativos recentes, obtidos por meio de duas análises de clusters, acoplamento de autores e coocorrência de palavras-chave; e a terceira propõe uma rede nomológica que demonstra os caminhos para melhorar a pesquisa quantitativa em estratégia de marketing usando analytics.

\section{Fundações do dueto entre marketing e analytics}

O presente trabalho fornece um resumo de vinte anos do desenvolvimento do analytics como um campo de pesquisa, destacando os principais pontos fortes da combinação dessa área com o marketing, especialmente a partir da perspectiva da literatura sobre capabilidades.

O termo geral analytics é considerado como um campo de estudo jovem, mas cada vez mais importante, caracterizado principalmente como o conjunto de técnicas, ferramentas e abordagens que objetivam a análise precisa dos dados de negócios para melhorar a tomada de decisões. A evolução desse campo multidisciplinar pode ser simplificada em três períodos principais, como proposto por Chen et al. (2012): BI\&A 1.0, BI\&A 2.0 e BI\&A 3.0.

O primeiro período ocorre na década de 1990, onde a combinação de técnicas estatísticas e práticas de mineração de dados leva ao desenvolvimento de melhores ferramentas analíticas, projetadas para a extração e armazenamento de informações em bancos de dados robustos (Chen et al., 2012). Portanto, o objetivo dos profissionais de marketing era otimizar a coleta, estruturação e posterior análise dos dados disponíveis no mercado.

O segundo período começa com a popularização da Internet em escala global, que transformou drasticamente a maneira como os dados são compartilhados e expandiu o volume 
de informações que podem ser acessadas. Esse cenário pode ser descrito como uma grande oportunidade para os profissionais de marketing, uma vez que a mudança para a comunicação digital afeta a fórmula do mix de marketing (Germann et al., 2014; Wedel \& Kannan, 2016), alterando os principais canais utilizados para produzir publicidade e gestão do relacionamento com o cliente.

O terceiro e mais recente período está diretamente relacionado à chamada Internet das Coisas (IoT) e ao fenômeno do big data. Isso abre uma nova perspectiva sobre como novos produtos de alta tecnologia podem ser usados como fonte de dados para fornecer informações úteis e individualizadas para aprimorar o conhecimento do mercado, embora também traga incerteza sobre as melhores técnicas e abordagens para coletar, processar e analisar dados (Chen et al., 2012).

O trabalho de Chen et al. (2012) fornece informações detalhadas sobre como a área de BI\&A evoluiu desde o seu início. Paralelamente, é necessário haver discussões sobre estratégia de negócios, principalmente relacionadas à visão baseada em recursos (Barney, 2014) e a literatura sobre capabilidades. No campo do marketing, as subáreas de comércio eletrônico e inteligência de mercado são as candidatas que mais se beneficiariam de todas as fontes de ferramentas analíticas (Chen et al., 2012). Mas, como essas abordagens analíticas podem ser vistas como uma capabilidade adequada, capaz de obter desempenho?

\section{Revisão bibliométrica}

Foi realizado um estudo bibliométrico nas bases Scopus e Web of Science para analisar o estado da arte que relacionam os termos marketing e analytics. A amostra foi criada usando a chave de pesquisa "marketing AND analytics AND (resources OR capabilities)" como critério de pesquisa em títulos, resumos e palavras-chave. Ressalta-se que o idioma escolhido foi o inglês e não houve restrições de tempo de publicação. As palavras-chave recursos ou capabilidades foram escolhidos como delimitação teórica do presente trabalho, visto que a visão baseada em recursos (RBV) e sua literatura subjacente sobre capabilidades como alicerce teórico do presente trabalho.

Foi confirmado que os artigos extraídos aderem à delimitação da pesquisa com uma leitura dos títulos, resumos e palavras-chave. Essas foram passadas para uma planilha, de onde outras teorias foram encontradas com ocorrências baixas, tais como: teoria da configuração, teoria dos jogos e a teoria da inovação, ao passo que a literatura sobre capabilidades e RBV apareceram com maior ocorrência. 
Segundo Quevedo-Silva, Santos, Brandão e Vils (2016), o método bibliométrico traz uma compreensão mais ampla de temas ou áreas, permitindo a identificação de tendências. De acordo com a revisão bibliográfica desses autores, esse tipo de estudo realiza três abordagens mutuamente não exclusivas: (i) descritiva, que traça linhas amplas ou os tópicos mais estudados em uma área, identificando grupos de pesquisa, ano de publicação, principais autores e métodos utilizados; (ii) sobre metodologia, que deve compreender o domínio metodológico da área pesquisada, classificando e contando os desenhos de pesquisa e as técnicas de teste mais utilizadas, adjacentemente, busca encontrar oportunidades de estudo e destacar uma determinada tradição de pesquisa na área; por fim, a abordagem de (iii) análise descritiva, que aprofunda o conhecimento usando a análise de cluster de autores, teorias e palavras-chave dos metadados da amostra.

A etapa descritiva foi utilizada para introduzir o presente estudo bibliométrico, mas a segunda etapa não foi realizada com a abordagem bibliométrica devido à delimitação escolhida da pesquisa. Em relação ao domínio metodológico, não foi realizada análise em todos os 705 artigos, pois foi escolhido realizar essa análise de maneira mais detalhada, começando com uma lista mais curta apresentada na seção de pesquisa aplicada. Finalmente, o último passo, na análise de cluster, são mostradas as tendências de pesquisa.

\section{Etapa descritiva}

As tabelas de 1 a 5 representam (i) uma abordagem descritiva, ao passo que a abordagem analítica (iii) foi alcançada principalmente com o uso de clusters sobre cocitações e acoplamento de autores e coocorrências de palavras-chave, culminando na associação de marketing e analytics por meio da literatura de capabilidades.

A Tabela 1 descreve as informações básicas desta amostra desde 1972; informações detalhadas por ano são apresentadas na Tabela 2. Destaca-se que apenas foram incluídos artigos de periódicos, excluindo revisões e trabalhos em conferências, workshops, editoriais e tutoriais. De um total de 898, contando as duas bases de extração, e após a exclusão das repetições, resultou-se em 778 artigos. A exclusão dos artigos foi executada pela função "mergeDbSources" do pacote "bibliometrix" (Aria \& Cuccurullo, 2017). 
Tabela 1 - Resultados bibliométricos - descrição geral

\section{Principais informações sobre a amostra}

Artigos

898

Fontes (Revistas)

412

Palavras-chave das revistas

1980

Palavras-chave dos autores 2014

Media de citações por artigo

9.321

Primeiros autores

1641

Ocorrências de autores

1999

Artigos do Scopus

499
Autores de artigos com apenas um autor

138

Autores de artigos com múltiplos autores

1479

Índice de artigos por autor

0.547

Índice de autor por artigos

1.82

Índice de Co-autores por artigo

2.71

Índice de colaboração

2.36

Período

$1972-$

2019

Artigos do Web of Science

399

Fonte: Elaborado pelos autores (2021). Utilizando o software R.

A Tabela 1 também descreve o número de artigos no Scopus e Web of Science, o número de fontes, palavras-chave usadas por autores e periódicos, autores e alguns índices que relacionam essas informações entre si.

Tabela 2 - Evolução anual do número de artigos

\begin{tabular}{ccccccccccccc}
\hline \multicolumn{10}{c}{ Produção Científica Anual } \\
\hline Ano & $\begin{array}{c}1972- \\
2008\end{array}$ & 2009 & 2010 & 2011 & 2012 & 2013 & 2014 & 2015 & 2016 & 2017 & 2018 \\
\hline Artigos & 72 & 26 & 27 & 22 & 42 & 50 & 74 & 101 & 152 & 128 & 161 \\
\hline \multicolumn{10}{c}{ Taxa de crescimento percentual anual: 3.93} \\
\hline
\end{tabular}

Fonte: Elaborado pelos autores (2021). Utilizando o software R.

De fato, de 1972 a 2008, apenas 72 artigos foram encontrados na amostra; portanto, a última década agrupou cerca de $92 \%$ dos artigos da amostra. O ano de 2019 foi excluído da tabela, mas apresentou 49 artigos publicados. O pacote bibliometrix (Aria \& Cuccurullo, 2017) usado pelo software R (R Core Team, 2019) calculou que há um crescimento anual positivo, demonstrando um interesse crescente no tópico de pesquisa. 
As informações da Tabela 3 demonstram que o Brasil não é um dos países centrais nas produções e citações dessa área. Ampliando a busca, o Brasil foi encontrado na $18^{a}$ posição do ranking.

Tabela 3 - Países mais produtivos

\begin{tabular}{lcccccc}
\hline & \multicolumn{2}{c}{ Total de artigos por país } & \multicolumn{3}{c}{ Total de citações por país } \\
\hline & PAİS & ARTIGOS & FREQ & PAÍS & CITAÇÕES & MÉDIA \\
\hline 1 & USA & 285 & 0.4241 & USA & 4358 & 15.291 \\
2 & England & 35 & 0.0521 & England & 332 & 9.486 \\
3 & China & 30 & 0.0446 & $\begin{array}{c}\text { United } \\
\text { Kingdom }\end{array}$ & 194 & 8.435 \\
4 & India & 25 & 0.0372 & Australia & 157 & 6.542 \\
\hline 5 & Australia & 24 & 0.0357 & Germany & 150 & 8.333 \\
\hline
\end{tabular}

Fonte: Elaborado pelos autores (2021). Utilizando o software R.

A Tabela 4 mostra que, para a amostra extraída das bases Web of Science e Scopus existem cinco periódicos conectados à literatura de sistemas de informação, um está relacionado à pesquisa operacional e dois ao marketing. $\mathrm{O}$ índice h5 também é apresentado nessa tabela, que é um índice h para artigos publicados nos últimos cinco anos completos. Segundo Hirsch (2005), o índice h é um excelente exemplo de métrica de citação que avalia a produtividade e o impacto de trabalhos publicados de um acadêmico ou periódico.

Tabela 4 - Fontes mais relevantes - Segunda etapa para iniciantes (onde pesquisar)

\begin{tabular}{lcccc}
\hline & FONTES & ARTIGOS & h5-index & JCR(2018) \\
\hline 1 & Expert Systems With Applications & 17 & 92 & 3.768 \\
\hline 2 & Decision Support Systems & 14 & 70 & 3.565 \\
\hline 3 & European Journal Of Operational Research & 13 & 82 & 3.428 \\
\hline 4 & IBM Journal Of Research And & 10 & 25 & 0.962 \\
\hline 5 & $\begin{array}{c}\text { Development } \\
\text { Computer Standards \& Interfaces }\end{array}$ & 10 & 26 & 1.465 \\
\hline 6 & International Journal Of Information \\
Management & 10 & 53 & 4.516 \\
\hline 7 & $\begin{array}{c}\text { Journal Of Direct Data And Digital } \\
\text { Marketing Practice }\end{array}$ & 10 & 8 & $\begin{array}{c}\text { não é mais } \\
\text { publicado }\end{array}$ \\
\hline 8 & Marketing Science & 10 & 40 & 2.794 \\
\hline
\end{tabular}

Fonte: Elaborado pelos autores (2021). Utilizando o software R. 
A Bibliometrix criou a Tabela 5 a partir de um total de 12.941 referências encontradas na amostra extraída. Portanto, são os artigos mais referenciados pelos autores. Embora todos esses trabalhos tenham sido avaliados e percebidos como potencialmente significativos na literatura existente que tenta associar marketing e analytics, o trabalho de Chen et al. (2012) deve ser destacado. Sua revisão bibliométrica e a rede nomológica não apenas mostram a importância do BI\&A, mas também demonstram as conexões com diferentes linhas de pesquisa, incluindo marketing.

Tabela 5 - Artigos mais referidos - Primeira etapa para iniciantes

\section{Artigos mais referenciados} Total

Chen, H., Chiang, R. H. L., \& Storey, V. C. (2012). Business Intelligence and Analytics : From Big Data To Big Impact. MIS Quarterly, 36(4), 1165-1188.

Bollen, J., Mao, H., \& Zeng, X. (2011). Twitter mood predicts the stock market. Journal of Computational Science, 2(1), 1-8. https://doi.org/10.1016/j.jocs.2010.12.007

Manyika, J., Chui, M., Brown, B., Bughin, J., Dobbs, R., Roxburgh, C., \& Byers, A. H. (2011). Big data: The next frontier for innovation, competition, and productivity. McKinsey Global Institute, (June), 156. https://doi.org/10.1080/01443610903114527

McAfee, A., \& Brynjolfsson, E. (2012). Big Data. The management revolution. Harvard Business Review, 90(10), 61-68. https://doi.org/10.1007/s12599-013$0249-5$

Antweiler, W., \& Frank, Z. M. (2004). Is All That Talk Just Noise? The Information Content of Internet Stock Message Boards. Journal of Finance, 59(3), 1259-1294. https://doi.org/10.1017/CBO9781107415324.004

Fonte: Elaborado pelos autores (2021). Utilizando o software R.

A maioria dos trabalhos é teórica ou não utiliza métodos quantitativos usuais da área de gestão. Os artigos apresentados na Tabela 5 são a fonte primária para os menos familiarizados com o assunto.

\section{Etapa analítica}

Um trabalho bibliométrico permite a combinação de uma enorme quantidade de dados bibliográficos por meio de análises estatísticas (Vogel \& Guttel, 2013). Iniciou-se uma etapa descritivo-analítica com a descrição da cocitação e acoplamento dos autores, seguido da 
apresentação gráfica da coocorrência das palavras-chave. Como opção estética, foi decidido não mostrar todas as análises de cluster em gráficos. A cocitação de autores tem um tamanho (número de vértices) de 5945, e Chen H. é o principal autor geral, índice de centralidade $(0,320)$ e índice de intermediação $(0,064)$. Esses índices destacaram o autor adotado como obra fundamental. A cocitação é razoável para interpretar as fundações de uma literatura; no entanto, para encontrar tendências, é necessária uma análise de acoplamento (Vogel \& Güttel, 2013).

A análise de acoplamento é uma técnica bibliométrica que mede a frequência em que dois documentos de uma amostra têm pelo menos uma referência em comum. Em seguida, considera a sobreposição de suas bibliografias (Kessler, 1963; Zupic \& Cater, 2015). O acoplamento bibliográfico muda a atenção das fundações para as tendências da literatura científica, aprimorando as aplicações bibliométricas (Vogel \& Guttel, 2013). A Figura 1 apresenta o acoplamento bibliográfico para a presente amostra.

Existem vários índices de centralidade usados para medir as maneiras pelas quais os autores podem se conectar. Para uma comparação detalhada e seu uso no marketing, consulte Chandler e Wieland (2010). Resumidamente, a centralidade de intermediação foi criada por Freeman (1978), e é o "menor número de conexões que passam pelo ator k que conectam o ator i e o ator j juntos" (Chandler \& Wieland, 2010, p. 205), ou seja, é uma medida de fluxo, significando que quanto maior o índice, maior a importância do ator (autor, universidade ou palavra-chave) para a literatura. Por exemplo, autores com índice mais alto se tornam conectores e outros autores podem se tornar dependentes deles como pontes para outros trabalhos, não diretamente conectados. 
Figura 1 - Acoplamento de autores

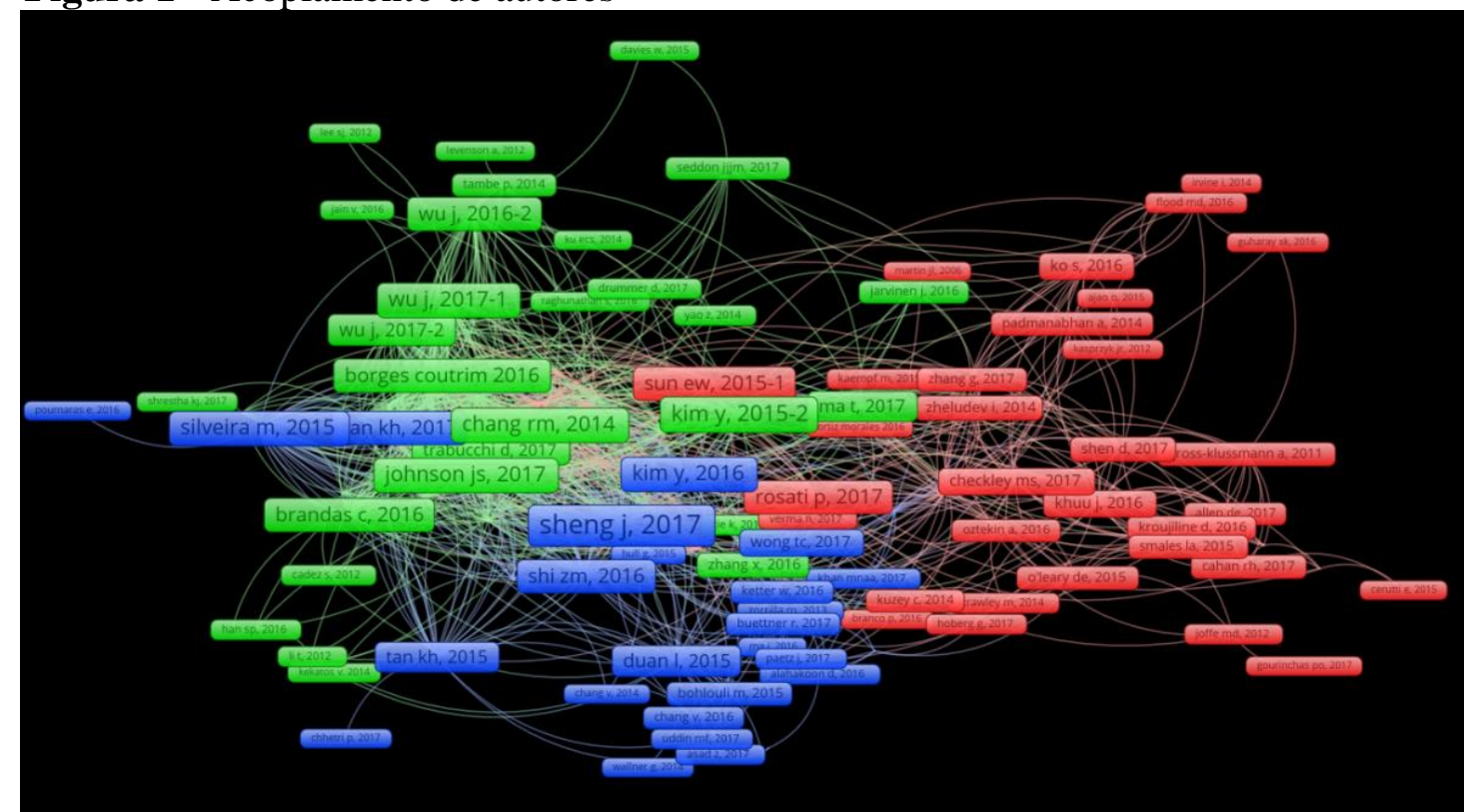

Fonte: Elaborado pelos autores (2021). Usando os softwares R e VOSViewer.

A Tabela 6 apresenta uma contagem fracionária do acoplamento dos autores. Quando a contagem fracionária é usada, há redução da influência de documentos com muitos autores (Perianes-Rodriguez, Waltman \& van Eck, 2016).

Como pode ser visto na Tabela 6 , o cluster vermelho possui índices de centralidade menores. Além disso, a Figura 1 o representa como uma literatura separada e separada do cluster azul e verde. De fato, o cluster vermelho apresenta mais documentos técnicos, aplicações em marketing (Huang, Fildes \& Soopramanien, 2014), finanças (Rosati et al., 2017) ou contabilidade (Chou, Chang \& Peng, 2016). Por exemplo, Huang, Fildes e Soopramanien (2014) discutem previsão de vendas, mas o foco está na melhor opção de algoritmo, comparando séries temporais e "atraso distribuído autoregressivo". Por seu lado, Chou, Chang e Peng (2016) discutem tecnologias semânticas da web para integrar divulgações contábeis textuais.

Por outro lado, com uma abordagem mais teórica, o cluster azul discute a aplicação de big data no suporte às operações da cadeia de suprimentos (Tan, Zhan, Ji, Ye e Chang, 2015) e tenta explicar como as organizações obtêm novas idéias de desenvolvimento de produtos ou otimizar seus processos de fabricação usando big data. Por sua vez, Sheng, Amankwah-amoah e Wang (2017) criaram uma revisão bibliográfica de big data e geraram uma framework para a agregação de valor e a prática de gerenciamento. Finalmente, Tan e Zhan (2017) também discutem o desenvolvimento de novos produtos em três empresas de eletrônicos como estudos 
de caso bem-sucedidos. Novamente, a maioria dos trabalhos é teórica ou não utiliza métodos quantitativos freqüentes de gerenciamento

Tabela 6 - Principais artigos por centralidade de intermediação por cluster

Artigo
Sheng, J., Amankwah-amoah, J., \& Wang, X. (2017). A multidisciplinary perspective
of big data in management research. International Journal of Production Economics,
191(November 2016), 97-112. https://doi.org/10.1016/j.ijpe.2017.06.006

Cluster Centralidade

Azul $\quad 386,98$

Kumar, A., Bezawada, R., Rishika, R., Janakiraman, R., \& Kannan, P. K. (2016). From Verde
social to sale: The effects of firm-generated content in social media on customer
behavior. Journal of Marketing, $80(1), 7-25$. https://doi.org/10.1509/jm.14.0249

Grover, P. (2017). Big Data Analytics: A Review on Theoretical Contributions and Verde 222,14

Tools Used in Literature. Global Journal of Flexible Systems Management, 18(3), 203-

229. https://doi.org/10.1007/s40171-017-0159-3

Johnson, J. S., Friend, S. B., \& Lee, H. S. (2017). Big Data Facilitation, Utilization, and
Monetization: Exploring the 3Vs in a New Product Development Process. Journal of
Product Innovation Management, 34(5), 640-658. https://doi.org/10.1111/jpim.12397

Tan, K. H., Zhan, Y. Z., Ji, G., Ye, F., \& Chang, C. (2015). Harvesting big data to Azul 216,23 enhance supply chain innovation capabilities: An analytic infrastructure based on deduction graph. International Journal of Production Economics, 165(July 2015), 223233. https://doi.org/10.1016/j.ijpe.2014.12.034

Tan, K. H., \& Zhan, Y. (2017). Improving new product development using big data: a Azul case study of an electronics company. $R$ and D Management, 47(4), 570-582. https://doi.org/10.1111/radm.12242

Rosati, P., Cummins, M., Deeney, P., Gogolin, F., van der Werff, L., \& Lynn, T. Vermelho 159,57 (2017). The effect of data breach announcements beyond the stock price: Empirical evidence on market activity. International Review of Financial Analysis, 49, 146-154. https://doi.org/10.1016/j.irfa.2017.01.001

Chou, C., Chang, C. J., \& Peng, J. (2016). Integrating XBRL data with textual Vermelho 75,88 information in Chinese: A semantic web approach. International Journal of Accounting Information Systems, 21, 32-46. https://doi.org/10.1016/j.accinf.2016.04.002

Huang, T., Fildes, R., \& Soopramanien, D. (2014). The value of competitive Vermelho 70,09
information in forecasting FMCG retail product sales and the variable selection
problem. European Journal of Operational Research, 237(2), 738-748.
https://doi.org/10.1016/j.ejor.2014.02.022

Fonte: Elaborado pelos autores (2021). Utilizando o software R.

O cluster verde está focado no marketing, e a maioria dos papéis está relacionada a seus problemas, principalmente a orientação ao cliente. Por exemplo, Johnson, Friend e Lee (2017) se concentram no desenvolvimento de novos produtos usando big data, contrastando exploration de exploitation em diferentes turbulências de mercado. Kumar et al. (2016) testaram empiricamente o desempenho do cliente usando mídias sociais como canal de comunicação de marketing por meio do marketing inbound. Além disso, Grover (2017) 
também discute vantagens competitivas e desempenho organizacional, seu foco está na evolução do big data em aplicações do analytics em mídias sociais, mineração de texto e aprendizado de máquina nas disciplinas de marketing e gerenciamento da cadeia de suprimentos, considerando uma visão geral das plataformas e ferramentas de vários setores.

Também analisamos a estrutura conceitual do campo com outra análise de rede, avaliando os clusters de coocorrência de palavras-chave. Este método utiliza o conteúdo real dos documentos para construir uma medida de similaridade (Callon, Courtial, Turner \& Bauin, 1983).

A Figura 2 mostra quase todos os vértices ou palavras-chave disponíveis. É uma matriz quadrada criada inicialmente com uma dimensão 1.909 das palavras-chave, também chamada matriz de similaridade, que resulta nas taxas de proximidade que são plotadas em um mapa usando o software livre VOSViewer (van Eck \& Waltman, 2010). Nas Figuras 1 e 2, foram adotadas medidas de similaridade probabilística para fins de normalização. O nome do método probabilístico no VosViewer é "Association strength", entendida como a melhor normalização para uma pesquisa cientométrica (Eck \& Waltman, 2009).

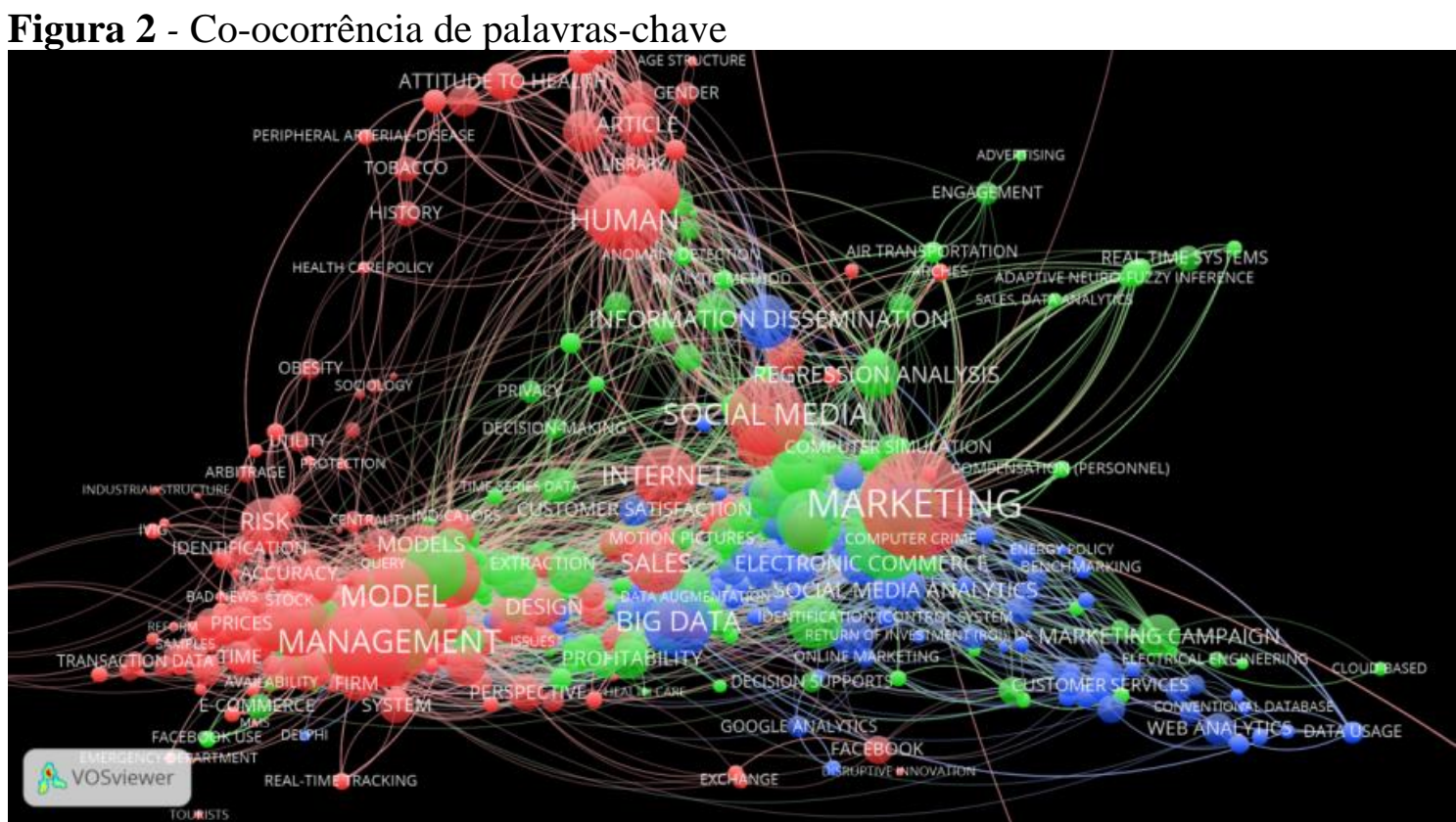

Fonte: Elaborado pelos autores (2021), usando os softwares R e VOSViewer.

O cluster vermelho foi classificado como "Gerenciamento de desempenho", com um total de 911 palavras-chave, relacionadas principalmente à literatura sobre gerenciamento / estratégia. Em seguida, o cluster azul foi categorizado como "Tecnologia e aprendizado". 
Possui 405 palavras-chave e está relacionado à uma literatura mais técnica ou de sistemas de informação. Por fim, o cluster verde foi classificado como "Orientação ao Cliente", com 653 palavras-chave, e está mais relacionado ao marketing. As palavras-chave mais importantes são referenciadas pelos clusters na Tabela 7 .

Tabela 7 - Principais palavras-chave - centralidade de intermediação por cluster

\begin{tabular}{|c|c|c|}
\hline Palavras-chave & Cluster & Centralidade \\
\hline Marketing & Vermelho & 248,17 \\
\hline Sales & Vermelho & 84,86 \\
\hline Management & Vermelho & 56,40 \\
\hline Social media & Azul & 51,41 \\
\hline Data mining & Azul & 34,50 \\
\hline Learning systems & $\overline{\text { Azul }}$ & 14,87 \\
\hline Big data & Azul & 14,12 \\
\hline Decision making & Verde & 12,68 \\
\hline $\begin{array}{c}\text { Artificial } \\
\text { intelligence }\end{array}$ & Azul & 10,84 \\
\hline Forecasting & Vermelho & 9,55 \\
\hline Model & Vermelho & 9,47 \\
\hline Profitability & Verde & 7,62 \\
\hline Algorithms & Azul & 7,22 \\
\hline Internet & Vermelho & 6,77 \\
\hline $\begin{array}{l}\text { Electronic } \\
\text { commerce }\end{array}$ & Verde & 6,72 \\
\hline $\begin{array}{l}\text { Information } \\
\text { dissemination }\end{array}$ & Azul & 5,39 \\
\hline
\end{tabular}

Fonte:Elaborado pelos autores (2021). Utilizando o software R.

Utilizamos a etapa analítica bibliométrica como um começo para entender melhor os construtos primários em uma etapa adicional que aprofunda a revisão da literatura utilizando capabilidades por meio de revistas de sistemas de informação, estratégia e marketing. O 
resultado dessa revisão se concentrou em trabalhos quantitativos nomeada como revisão aplicada.

\section{Revisão aplicada: tendências}

Como a maioria dos trabalhos é teórica ou não utiliza métodos quantitativos freqüente em gestão, também foi realizada uma revisão bibliográfica aplicada (Tabela 8) em periódicos internacionais com índices JCR significativos, deliberados como mais de um, e disponíveis em periodicos.capes.gov.br. Os construtos pesquisados estão relacionadas a "Gerenciamento de desempenho", "Tecnologia e Aprendizado" ou "Orientação ao Cliente".

Para esta revisão bibliográfica aplicada, seguimos as diretrizes de Hong, Chan, Thong, Chasalow e Dhillon (2013) quanto a construtos contextuais, ou seja, construtos semelhantes com nomes diferentes dependendo do contexto. Portanto, considerou-se termos como big data analytics, analytics com mídias sociais, marketing analytics e analytics de clientes como construtos relacionados em contextos específicos de um construto geral de business analytics, seguindo Chen et al. (2012). Foi necessário analisar trabalhos quantitativos usando todos esses termos. 
Tabela 8 - Resumo dos estudos aplicados

\begin{tabular}{|c|c|c|}
\hline Referencia & Construtos (em inglês) & is resultados \\
\hline $\begin{array}{l}\text { (Chang et } \\
\text { al., 2010) }\end{array}$ & $\begin{array}{l}\text { 1.1Customer-centric organizational culture } \\
\text { 1.2Customer-centric management system } \\
\text { 2.CRM technology use } \\
\text { 3.Marketing capabilities } \\
\text { 4.Organizational performance }\end{array}$ & $\begin{array}{l}\text { A capabilidade de marketing é } \\
\text { mediadora entre o uso do CRM e } \\
\text { o desempenho organizacional }\end{array}$ \\
\hline $\begin{array}{l}\text { (Trainor et } \\
\text { al., 2014) }\end{array}$ & $\begin{array}{l}\text { 1.1Customer-Centric Management System } \\
\text { 1.2-Social Media Technology Use } \\
\text { 2-Social CRM capabilities } \\
\text { 3-Customer Relationship performance } \\
\text { Covariate(Cov)1-Training } \\
\text { Cov2-Management Support } \\
\text { Cov3-Organizational Size }\end{array}$ & $\begin{array}{l}\text { O uso de tecnologias de mídias } \\
\text { sociais não tem, por si própria, } \\
\text { um efeito direto desempenho do } \\
\text { relacionamento com o cliente }\end{array}$ \\
\hline $\begin{array}{l}\text { (Wamba et } \\
\text { al., 2017) }\end{array}$ & $\begin{array}{l}\text { 1.1-BDA(big data analytics) infrastructure } \\
\text { capability } \\
\text { 1.2-BDA management capability } \\
\text { 1.3- BDA personnel capability } \\
\text { 2- BDA capability } \\
\text { 3-process-oriented dynamic capabilities } \\
\text { 4-Performance }\end{array}$ & $\begin{array}{l}\text { Impacto direto da capabilidade } \\
\text { analítica do big data em } \\
\text { desempenho, ocorre apenas com } \\
\text { o efeito mediador da } \\
\text { capabilidade de orientação a } \\
\text { processo sobre esse } \\
\text { relacionamento }\end{array}$ \\
\hline $\begin{array}{l}\text { (Côrte- } \\
\text { Real et al., } \\
2017)\end{array}$ & $\begin{array}{l}\text { 1.1-endogenous knowledge management } \\
\text { 1.2-exogenous knowledge management } \\
\text { 1.3-knowledge sharing with partners } \\
\text { 2-Agility } \\
\text { 3-Process-level performance } \\
\text { 4-competitive advantages } \\
\text { cov1-“time since adoption of BDA"; cov2- } \\
\text { industry; cov3-country; cov4-technological } \\
\text { turbulence; cov5 -Leadership in } \\
\text { product/process innovation; cov6- Impact of } \\
\text { new technology on operations. }\end{array}$ & $\begin{array}{l}\text { Para criar agilidade, } \\
\text { conhecimento externo a partir de } \\
\text { aplicações de big data analytics } \\
\text { pode ser mais efetivo que } \\
\text { conhecimento interno }\end{array}$ \\
\hline $\begin{array}{l}\text { (Chuang \& } \\
\text { Lin, 2017) }\end{array}$ & $\begin{array}{l}\text { 1.1- e-service capability } \\
\text { 1.2 - service innovation orientation } \\
\text { 2- information-value offering } \\
\text { 3- Customer relationship performance } \\
\text { 4-Organizational performance } \\
\text { cov- market turbulence }\end{array}$ & $\begin{array}{l}\text { O efeito positivo do valor da } \\
\text { informação no desempenho do } \\
\text { relacionamento com o cliente e } \\
\text { no desempenho organizacional se } \\
\text { torna evidente em mercados } \\
\text { altamente turbulentos }\end{array}$ \\
\hline $\begin{array}{l}\text { (Popovič, } \\
\text { Hackney, } \\
\text { Coelho, \& } \\
\text { Jaklič, } \\
\text { 2014) }\end{array}$ & $\begin{array}{l}\text { 1-Information sharing values (ISV) } \\
\text { 2.1-BI system quality (BISQ) } \\
\text { 2.2 -Information quality (IQ) } \\
\text { 3-Information use (IU) }\end{array}$ & $\begin{array}{l}\text { O valor da informação } \\
\text { compartilhada é mediadora entre } \\
\text { as dimenções dos sistemas de } \\
\text { informação. }\end{array}$ \\
\hline $\begin{array}{l}\text { (Chuang \& } \\
\text { Lin, 2013) }\end{array}$ & $\begin{array}{l}\text { 1-Technology resource } \\
\text { 2-Human resource } \\
\text { 3-Business resource } \\
\text { 4-Customer orientation } \\
\text { 5-Customer information quality } \\
\text { 6-Customer relationship performanc } \\
\text { 7-Overall firm performance }\end{array}$ & $\begin{array}{l}\text { O desempenho } r \\
\text { relacionamento com o cliente } \\
\text { tem um papel mediador no } \\
\text { relacionamento entre a qualidade } \\
\text { da informação sobre o cliente e o } \\
\text { desempenho global da } \\
\text { organização. }\end{array}$ \\
\hline
\end{tabular}

Fonte: Elaborado pelos autores (2021). 
Por delimitação, foram incluídos apenas os artigos que exibiram o modelo estrutural e suas respectivas medidas. Outros trabalhos, não selecionados inicialmente, foram incluídos por ramificação bola de neve dos artigos escolhidos inicialmente.

A Tabela 8 revela uma lista de pesquisas aplicadas selecionadas com modelos quantitativos explícitos desde o ano de 2010, de onde futuros estudos podem ser operacionalizados a partir das opções de construtos da rede nomológica (veja a Figura 4). O marketing analytics pode ser estudado do ponto de vista da literatura sobre capabilidades (Germann et al., 2014; Wamba et al., 2017), mas um mapeamento da literatura mostra diferentes níveis de abstrações e alguns problemas desafiadores (veja a Figura 3). A Figura 3 ajuda a explicar a base / escolhas teóricas do presente trabalho.

A Figura 3 mostra, no lado esquerdo, os níveis de abstração encontrados na literatura de marketing e estratégia sobre recursos. Isso significa que é possível falar sobre recursos em nível geral e 3 níveis de recursos de marketing, de acordo com Day $(2011,2014)$. E o lado direito interconecta as três literaturas que o presente trabalho usa.

Figura 3 - Níveis de abstração da literatura

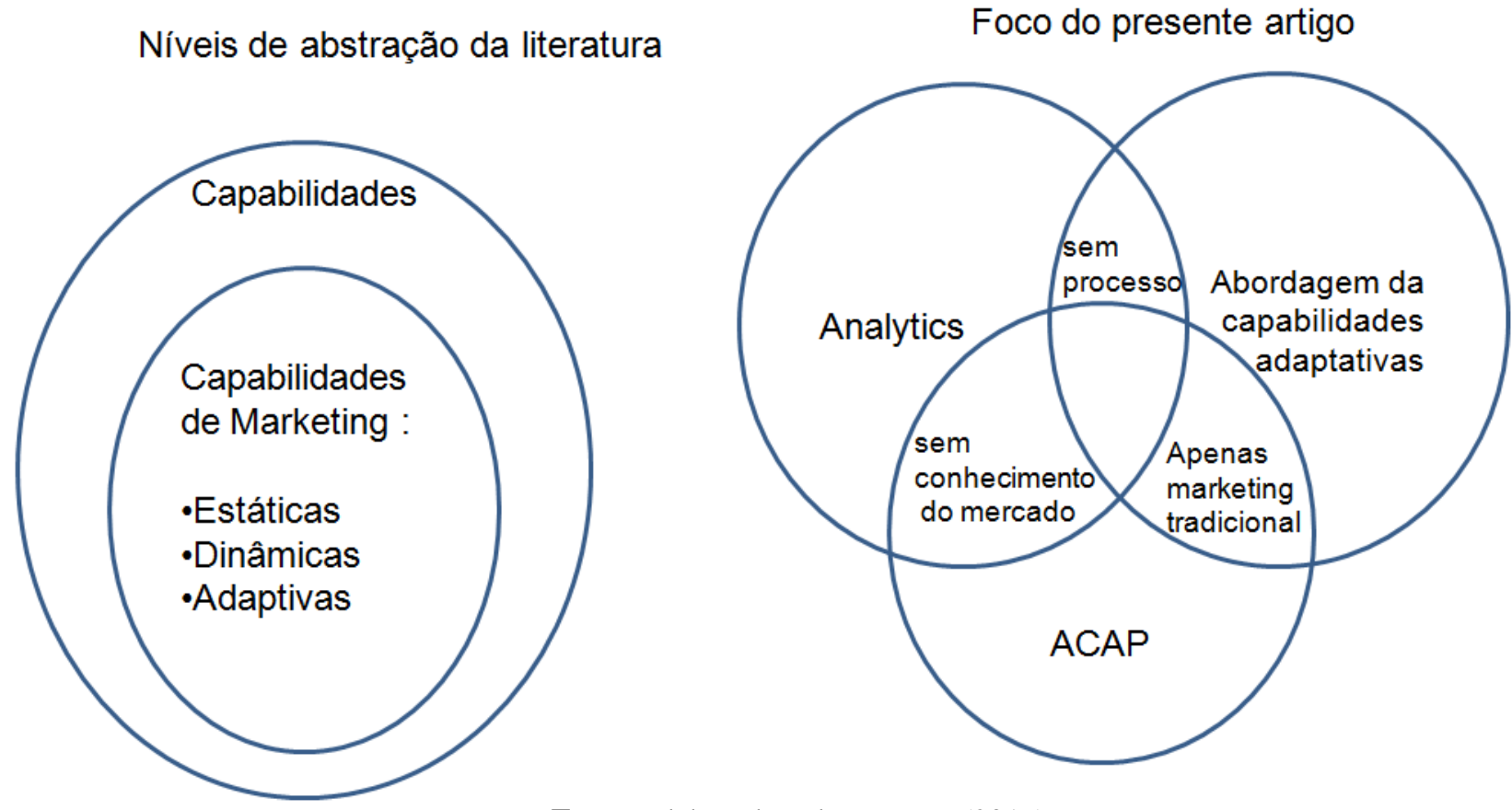

Fonte: Elaborado pelos autores (2019).

No lado direito, as interseções representam oportunidades ou questões de pesquisa. A interseção 1 (sem conhecimento de mercado) da Figura 3 está relacionada à forma como a literatura de sistemas de informação utiliza capabilidades para explicar o processo de 
aprendizagem, mas essas abordagens não se concentram na aprendizagem de conhecimento de mercado (Teo, Nishant \& Koh, 2016; Wang \& Byrd , 2017), e o conhecimento do mercado é vital para a mudança de estratégias organizacionais (Barrales-Molina et al., 2014).

A interseção 2 (apenas marketing tradicional) da Figura 3 está relacionada a como a literatura do marketing e estratégia usa o conceito de capacidade absortiva (ACAP) do processo de aprendizado. Utiliza processos de exploration e exploitation ou usa a orientação para o mercado de forma responsiva ou proativa (Barrales-Molina et al., 2014; Ozdemir, Kandemir, \& Eng, 2017). Essa literatura é proeminente, mas falta discutir analytics; assim, permanece nos métodos tradicionais de marketing (Wedel \& Kannan, 2016); não diminuindo a lacuna das capabilidades de marketing.

As disciplinas do marketing (Germann et al., 2014; Wang \& Hajli, 2017) e sistemas de informação (Pavlou \& Sawy, 2010; Teo et al., 2016) estão interessadas no processo de aprendizado via exploration e exploitation do conhecimento do mercado. No entanto, Day (2011) propôs dimensões antecipatórias e experimentais para fechar a lacuna das capabilidades de marketing, e a interseção 3 (sem processo de aprendizado) da Figura 3 oferece essa oportunidade de explicar a abordagem de Day usando analytics, mas ainda a última pergunta sobre o processo de aprendizado tem sua resposta na interseção das três literaturas.

Em suma, nós propomos um construto, capabilidades analíticas adaptativas, como a interseção completa da figura 3.

\section{Rede nomológica: tendências}

A Figura 4 propõe as capabilidades analíticas adaptativas como o construto exógeno principal da rede nomológica desenvolvida a partir da revisão aplicada. 
Figura 4 - Rede nomológica

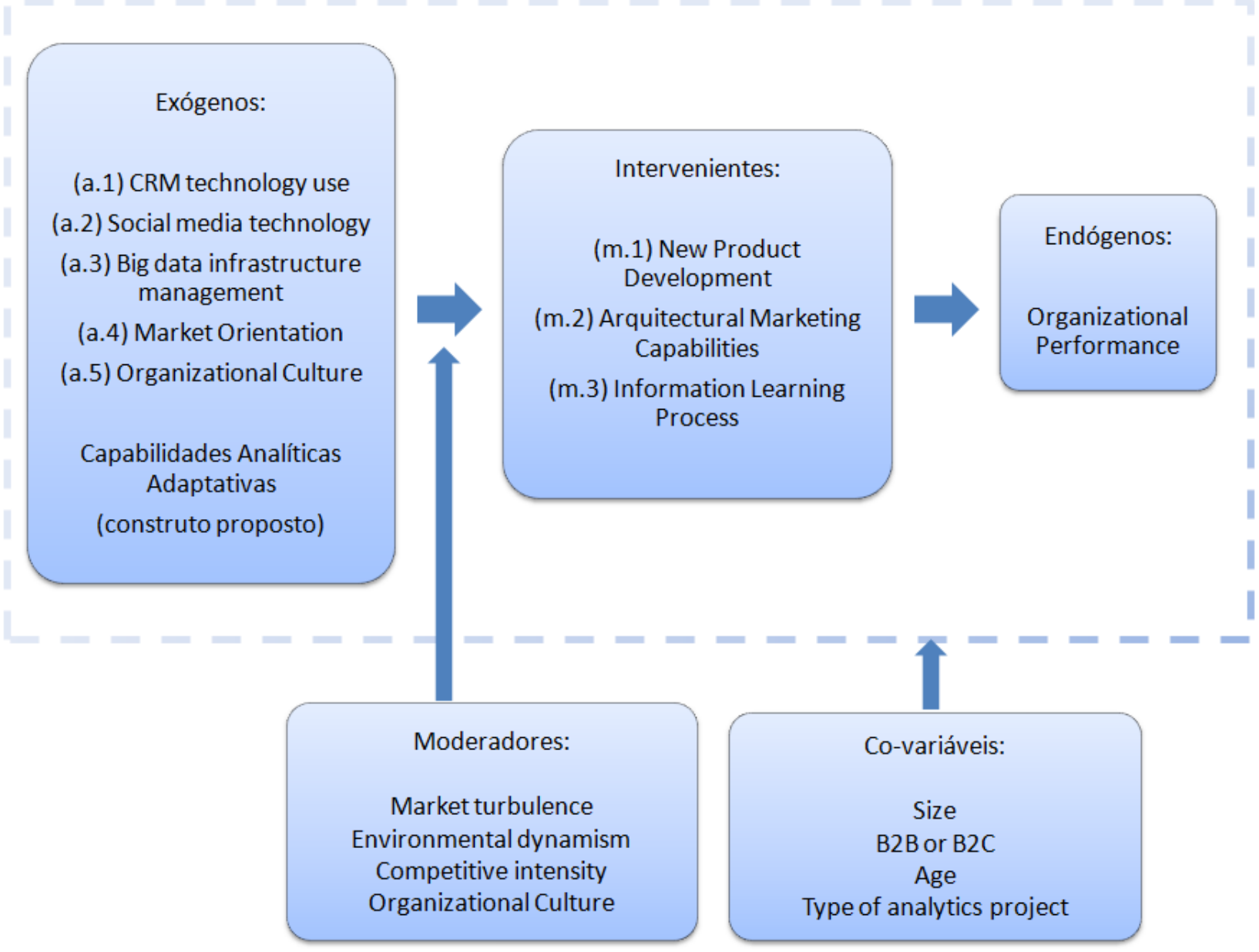

Fonte: Elaborado pelos autores (2021).

A Figura 4 mostra os construtos exógenos, as covariáveis, os moderadores, intervenientes e endógenos sugeridos na revisão sistemática. Alguns artigos de referência possíveis para os construtos exógenos são (a.1) (Chang et al., 2010), (a.2): (Trainor et al., 2014), (a.3) (Wamba et al., 2017) , (a.4) (Rapp et al., 2010) e (a.5) (Chang et al., 2010; Trainor et al., 2014). Já as covariáveis, os moderadores e o construto desempenho são de fontes recorrentes da literatura (Jayachandran, Sharma, Kaufman \& Raman, 2005; Rapp el al., 2010). Finalmente, os trabalhos de referência para intervenientes / mediações são (m.1) (Xu et al., 2016), (m.2) (Morgan, Zou, Vorhies e Katsikeas, 2003) e (m.3) (Cohen \& Levinthal, 1990). 


\section{Discussões}

Analisamos os clusters nas Figuras 1 e 2 e Tabelas 7 e 8; em primeiro lugar, foi visto que o cluster "Orientação ao Cliente" parece ser um tópico central na interseção entre marketing e analytics. Esse cluster envolve principalmente a análise de dados estruturados ou texto, mídias sociais, dados móveis, etc., para fins de marketing e gestão de operações. Os sentimentos e o comportamento do consumidor são difíceis de serem entendido devido à turbulência do mercado / cliente (Johnson, Friend \& Lee, 2017), mas está no foco de analistas sociais, especialmente em marketing.

Em segundo lugar, no cluster "Gerenciamento de desempenho", big data está badalado (Grover, 2017; Tan, Zhan, Ji, Ye e Chang, 2015). Novas abordagens do marketing analytics tentam melhorar o desempenho organizacional (Kim, Jo \& Shin, 2016). Muitos trabalhos prevêem o impacto do big data no desempenho, e suas mudanças no gerenciamento e na estratégia também são discutidas (Sheng, Amankwah-amoah, \& Wang, 2017).

Em terceiro lugar, os artigos do cluster "Tecnologia e aprendizado" geralmente lidam com técnicas de analytics / ciência de dados e questões tecnológicas. Essas tecnologias aprimoram a coleta de informações e o processamento de dados de mercado para prever, por exemplo, comportamentos / sentimentos do cliente (Kumar et al., 2016). O principal objetivo de alguns desses artigos é aumentar a eficiência operacional usando analytics e capabilidades (Popovič, Hackney, Tassabehji, \& Castelli, 2016; Chen \& Nath, 2018).

Uma etapa recorrente e vital para desenvolver um modelo é o processo de escolha dos construtos (MacKenzie, Podsakoff, \& Podsakoff, 2011), e uma rede nomológica pode ajudar com isso (veja a Figura 4). Essa etapa é especialmente crucial para os construtos latentes do marketing (Jarvis, MacKenzie e Podsakoff, 2004). Assim, após a revisão sistemática de artigos quantitativos, a Figura 4 propôs uma rede nomológica inicial. Antes disso, a Figura 3 apresentava os problemas / lacunas da literatura e oferecia as capabilidades analíticas adaptativas como uma resposta para esses problemas.

Engendramos as capabilidades analíticas adaptativas após a leitura dos artigos separados pelas análise dos cluster dos autores. Inferimos que os clusters verde e azul estão principalmente relacionados a artigos de negócios, gerenciamento e marketing. O cluster verde pode ser conectado com "Orientação ao Cliente", o azul com "Gerenciamento de Desempenho" e o cluster vermelho pode ser vinculado a "Tecnologia e Aprendizado", representando um cluster com viés mais computacional ou tecnológico. Portanto, capabilidades analíticas adaptativas tentam conectar esses três clusters. 
As capabilidades analíticas adaptativas podem representar um processo de aprendizado que se preocupa com o conhecimento do mercado e supera os métodos tradicionais de marketing usando o Analytics. A rede nomológica é útil no desenvolvimento de modelos futuros, com o objetivo de adotar as capabilidades analíticas adaptativas, sua relação com o desempenho organizacional e também apresenta as variáveis candidatas mais críticas no contexto para análises de moderação e mediação.

\section{Conclusões}

O presente trabalho serve como um guia para o estudo da área emergente do analytics em marketing usando a literatura de capabilidades. Semelhante a Chen et al. (2012), foi realizado um estudo bibliométrico para elevar o estado da arte das discussões acadêmicas em torno do BI\&A e, em seguida, combiná-lo com publicações relacionadas à RBV / capabilidades. Funciona como base para uma melhor compreensão do fenômeno por iniciantes (veja Tabelas 4 e 5) e um atalho para pesquisadores avançados (veja Tabela 8 e Figura 4).

Além da análise bibliométrica, foi realizada uma revisão aplicada para gerar uma rede nomológica após a leitura de todos os resumos da amostra e todo o conteúdo dos artigos das Tabelas 5, 6 e 8. Também foram relatadas as variáveis operacionalizadas, mais utilizadas e consistentes com as teorias relacionadas ao fenômeno, juntamente com possíveis co-variáveis e outras variáveis intervenientes. Assim, a principal contribuição do presente trabalho é fornecer opções de modelos teóricos usando pesquisas anteriores para facilitar futuros estudos quantitativos sobre a interseção entre marketing e analytics.

"Orientação ao Cliente", "Tecnologia e Aprendizagem" e "Gerenciamento de Desempenho" são as tendências. Além disso, a revisão demonstra que as tecnologias que facilitam as interações diretas entre organizações e clientes podem aumentar as ofertas / desenvolvimento de produtos e serviços. Portanto, a orientação ao cliente usando analytics está badalada como um novo elemento central da estratégia de marketing. Neste contexto, o big data está ainda mais badalado (Johnson, Friend \& Lee, 2017). A literatura também apresenta soluções para mercados mais especializada como segmentação / personalização, avançando áreas como a pesquisa de marca e a publicidade (Kumar et al., 2016). Estas tendências compõem a agenda de pesquisa.

Uma oportunidade vem do teste de alguns dos possíveis relacionamentos da rede nomológica (veja a Figura 4). Estudos futuros podem se concentrar nos impactos dos 
mecanismos adaptativos sustentados pelo analytics. Construtos exógenos da rede nomológica podem ser vistos como elementos de dependência de caminho que, em seguida, podem ser estudados usando uma abordagem longitudinal para entender o processo de construção dessas dependências de caminhos com qualquer outro moderador, mediador ou co-variável apresentado. As idiossincrasias das indústrias podem contar a história em termos de dependência de caminho das capabilidades.

Novos trabalhos quantitativos podem seguir a ideia de alguns estudos atuais que forneceram evidências empíricas que confirmam o papel desenvolvido pelas capabilidades organizacionais para gerar dinamismo a partir de sua equipe de inovação / tecnologia (Barrales-Molina et al., 2014). Algum trabalho quantitativo pode estudar vantagens competitivas sustentadas / duráveis ou temporárias / transitórias (Day, 2014). Em qualquer um desses cenários, propõe-se que estudos futuros incluam construtos relacionados à tecnologia, como capacidade da equipe, uso da tecnologia, infra-estrutura tecnológica, gerenciamento / liderança da tecnologia e / ou orientação à inovação.

Este artigo sugere o desempenho como um construto endógeno primário. É certo que é possível lidar com relacionamentos com clientes, desempenho do marketing, do financeiro ou de outros tipos, com abordagens subjetivas ou objetivas. Por outro lado, existem muitas possibilidades endógenas e sugerimos algumas na rede nomológica.

As co-variáveis mostradas na Figura 4 incentivam a pesquisa sobre desempenho e seus antecedentes, além de moderação e / ou mediação e / ou co-variáveis típicas de construtos comuns, como treinamento, suporte gerencial, tamanho, indústria, país e / ou construtos mais interessantes, tais como dinamismo ambiental, liderança em inovação, cultura, impacto de novas tecnologias, mercado ou turbulência tecnológica. Com certeza, essa não é uma lista completa, mas apresenta milhares de possibilidades para explicar o desempenho em diferentes contextos.

A partir dessa infinidade de possibilidades de modelagem, há uma questão interessante não discutida no presente artigo e mostrada na rede nomológica (veja a Figura 4): Como a cultura organizacional é inserida no modelo? Como construto exógeno, como moderador ou como parte do construto das capabilidades analíticas adaptativas? 


\section{Referências}

Aria, M., \& Cuccurullo, C. (2017). bibliometrix: An R-tool for comprehensive science mapping analysis. Journal of Informetrics, 11(4), 959-975.

https://doi.org/10.1016/j.joi.2017.08.007.

Barney, J. B. (2014). How marketing scholars might help address issues in resource-based theory. Journal of the Academy of Marketing Science, 42(1), 24-26. https://doi.org/10.1007/s11747-013-0351-8.

Barrales-Molina, V., Martínez-López, F. J., \& Gázquez-Abad, J. C. (2014). Dynamic marketing capabilities: Toward an integrative framework. International Journal of Management Reviews, 16(4), 397-416. https://doi.org/10.1111/ijmr.12026.

Braganza, A., Brooks, L., Nepelski, D., Ali, M., \& Moro, R. (2017). Resource management in big data initiatives: Processes and dynamic capabilities. Journal of Business Research, 70, 328-337. https://doi.org/10.1016/j.jbusres.2016.08.006.

Callon, M., Courtial, J. P., Turner, W. A., \& Bauin, S. (1983). From translations to problematic networks: An introduction to co-word analysis. Social Science Information, 22(2), 191-235. https://doi.org/10.1177/053901883022002003.

Chandler, J. D., \& Wieland, H. (2010). Embedded Relationships: Implications for Networks, Innovation, and Ecosystems. Journal of Business Market Management, 4(4), 199-215. https://doi.org/10.1007/s12087-010-0041-5.

Chang, W., Park, J. E., \& Chaiy, S. (2010). How does CRM technology transform into organizational performance? A mediating role of marketing capability. Journal of Business Research, 63(8), 849-855. https://doi.org/10.1016/j.jbusres.2009.07.003.

Chen, L., \& Nath, R. (2018). Business analytics maturity of firms: an examination of the relationships between managerial perception of IT, business analytics maturity and success. Information Systems Management, 35(1), 62-77. https://doi.org/10.1080/10580530.2017.1416948.

Chen, H., Chiang, R. H. L., \& Storey, V. C. (2012). Business Intelligence and Analytics: From Big Data To Big Impact. MIS Quarterly, 36(4), 1165-1188.

Chou, C., Chang, C. J., \& Peng, J. (2016).Integrating XBRL data with textual information in Chinese : A semantic web approach. International Journal of Accounting Information Systems, 21, 32-46. https://doi.org/10.1016/j.accinf.2016.04.002.

Chuang, S.-H., \& Lin, H.-N. (2013). The roles of infrastructure capability and customer orientation in enhancing customer-information quality in CRM systems: Empirical evidence from Taiwan. International Journal of Information Management, 33(2), 271-281. https://doi.org/10.1016/j.ijinfomgt.2012.12.003.

Chuang, S. H., \& Lin, H. N. (2017). Performance implications of information-value offering in e-service systems: Examining the resource-based perspective and innovation strategy. 
Journal of Strategic Information Systems, 26(1), 22-38.

https://doi.org/10.1016/j.jsis.2016.09.001.

Cohen, W. M., \& Levinthal, D. A. (1990). Absorptive Capacity : A New Perspective on Learning and Innovation. Administrative Science Quarterly, 35(1), 128-152. https://doi.org/10.2307/2393553.

Conti, C. R., Parente, R., \& de Vasconcelos, F. C. (2015).When distance does not matter: Implications for Latin American multinationals. Journal of Business Research, 69(6), 1980-1992. https://doi.org/10.1016/j.jbusres.2015.10.144.

Cooke, A. D. J., \& Zubcsek, P. P. (2017). The Connected Consumer: Connected Devices and the Evolution of Customer Intelligence. Journal of the Association for Consumer Research, 2(2).

Côrte-Real, N., Oliveira, T., \& Ruivo, P. (2017).Assessing business value of Big Data Analytics in European firms. Journal of Business Research, 70, 379-390. https://doi.org/10.1016/j.jbusres.2016.08.011.

Day, G. S. (2011).Closing the Marketing Capabilities Gap. Journal of Marketing, 75(4), 183195. https://doi.org/10.1509/jmkg.75.4.183, G. S. (2014).An outside-in approach to resource-based theories. Journal of the Academy of Marketing Science, 42(1), 27-28. https://doi.org/10.1007/s11747-013-0348-3.

Freeman, L. C. (1978). Centrality in Social Networks Conceptual Clarification. Social Networks, 1, 215-239.

Germann, F., Lilien, G. L., Fiedler, L., \& Kraus, M. (2014). Do Retailers Benefit from Deploying Customer Analytics? Journal of Retailing, 90(4), 587-593. https://doi.org/10.1016/j.jretai.2014.08.002.

Grover, P. (2017). Big Data Analytics : A Review on Theoretical Contributions and Tools Used in Literature. Global Journal of Flexible Systems Management, 18(3), 203-229. https://doi.org/10.1007/s40171-017-0159-3.

Hirsch, J. E. (2005). An index to quantify an individual's scientific research output. Proceedings of the National Academy of Sciences of the United States of America, 102(46), 16569-16572. https://doi.org/10.1073/pnas.0507655102.

Hong, W., Chan, F. K. Y., Thong, J. Y. L., Chasalow, L. C., \& Dhillon, G. (2013). A Framework and Guidelines for Context-Specific Theorizing in Information Systems Research. Information Systems Research, 7047(2004), 1-26.

Jarvis, C. B., MacKenzie, S. B., \& Podsakoff, P. M. (2004).A Critical Review of Construct Indicators and Measurement Model Misspecification in Marketing and Consumer Research. Journal of Consumer Research, 30(September 2003), 199-218. https://doi.org/10.1086/376806. 
Jayachandran, S., Sharma, S., Kaufman, P., \& Raman, P. (2005).The role of relational information processes and technology use in customer relationship management. Journal of Marketing, 69(4), 177-192. https://doi.org/10.1509/jmkg.2005.69.4.177.

Johnson, J. S., Friend, S. B., \& Lee, H. S. (2017). Big Data Facilitation, Utilization, and Monetization: Exploring the 3Vs in a New Product Development Process. Journal of Product Innovation Management, 34(5), 640-658. https://doi.org/10.1111/jpim.12397.

Kessler, M. M. (1963). Bibliographic Coupling Between Scientific Papers. American Documentation, 14(1), 10-25.

Khanagha, S., Volberda, H., \& Oshri, I. (2017). Customer Co-Creation and Exploration of Emerging Technologies: The Mediating Role of Managerial Attention and Initiatives. Long Range Planning, 50, 221-242. https://doi.org/10.1016/j.lrp.2015.12.019.

Kim, H. J., Jo, N. O., \& Shin, K. S. (2016).Optimization of cluster-based evolutionary undersampling for the artificial neural networks in corporate bankruptcy prediction. Expert Systems with Applications, 59, 226-234. https://doi.org/10.1016/j.eswa.2016.04.027.

Kumar, A., Bezawada, R., Rishika, R., Janakiraman, R., \& Kannan, P. K. (2016). From social to sale: The effects of firm-generated content in social media on customer behavior. Journal of Marketing, 80(1), 7-25. https://doi.org/10.1509/jm.14.0249.

MacKenzie, Podsakoff, \& Podsakoff. (2011). Construct Measurement and Validation Procedures in MIS and Behavioral Research: Integrating New and Existing Techniques. MIS Quarterly, 35(2), 293. https://doi.org/10.2307/23044045.

MacRoberts, M. H., \& MacRoberts, B. R. (2010). Problems of citation analysis: A study of uncited and seldom-cited influences. Journal of the American Society for Information Science and Technology, 61(1), 1-12. https://doi.org/10.1002/asi.21228.

Morgan, N. A., Zou, S., Vorhies, D. W., \& Katsikeas, C. S. (2003). Experiential and Informational Knowledge, Architectural Marketing Capabilities, and the Adaptive Performance of Export Ventures: A Cross-National Study. Decision Sciences, 34(2), 287321. https://doi.org/10.1111/1540-5915.02375.

Ozdemir, S., Kandemir, D., \& Eng, T. (2017).The role of horizontal and vertical new product alliances in responsive and proactive market orientations and performance of industrial manufacturing firms. Industrial Marketing Management, 64(July), 25-35. https://doi.org/10.1016/j.indmarman.2017.03.006.

Pavlou, P. A., \& Sawy, O. A. E. (2010). The "third hand": IT-enabled competitive advantage in turbulence through improvisational capabilities. Information Systems Research, 21(3), 443-471. https://doi.org/10.1287/isre.1100.0280.

Popovič, A., Hackney, R., Coelho, P. S., \& Jaklič, J. (2014). How information-sharing values influence the use of information systems: An investigation in the business intelligence systems context. The Journal of Strategic Information Systems, 23, 270-283. https://doi.org/10.1016/j.jsis.2014.08.003. 
Popovič, A., Hackney, R., Tassabehji, R., \& Castelli, M. (2016). The impact of big data analytics on firms ' high value business performance. Information Systems Frontiers, 20(2), 209-222. https://doi.org/10.1007/s10796-016-9720-4.

Quevedo-Silva, F., Santos, E. B. A., Brandão, M. M., \& Vils, L. (2016). ESTUDO BIBLIOMÉTRICO: ORIENTAÇÕES SOBRE SUA APLICAÇÃO. Revista Brasileira de Marketing, 15(2), 246-262. https://doi.org/10.5585/remark.v15i2.3274.

R Core Team (2019). R: A language and environment for statistical computing. R Foundation for Statistical Computing, Vienna, Austria.URL https://www.R-project.org/.

Rapp, A., Trainor, K. J., \& Agnihotri, R. (2010). Performance implications of customerlinking capabilities: Examining the complementary role of customer orientation and CRM technology. Journal of Business Research, 63(11), 1229-1236. https://doi.org/10.1016/j.jbusres.2009.11.002.

Rosati, P., Cummins, M., Deeney, P., Gogolin, F., van der Werff, L., \& Lynn, T. (2017). The effect of data breach announcements beyond the stock price: Empirical evidence on market activity. International Review of Financial Analysis, 49, 146-154. https://doi.org/10.1016/j.irfa.2017.01.001.

Sheng, J., Amankwah-amoah, J., \& Wang, X. (2017).A multidisciplinary perspective of big data in management research. International Journal of Production Economics, 191(November 2016), 97-112. https://doi.org/10.1016/j.ijpe.2017.06.006.

Tan, K. H., \& Zhan, Y. (2017). Improving new product development using big data: a case study of an electronics company. $R$ and D Management, 47(4), 570-582. https://doi.org/10.1111/radm.12242.

Tan, K. H., Zhan, Y. Z., Ji, G., Ye, F., \& Chang, C. (2015). Harvesting big data to enhance supply chain innovation capabilities: An analytic infrastructure based on deduction graph. International Journal of Production Economics, 165(July 2015), 223-233. https://doi.org/10.1016/j.ijpe.2014.12.034.

Teo, T. S. H., Nishant, R., \& Koh, P. B. L. (2016). Do shareholders favor business analytics announcements? Journal of Strategic Information Systems, 25(4), 259-276. https://doi.org/10.1016/j.jsis.2016.05.001.

Trainor, K. J., Andzulis, J., Rapp, A., \& Agnihotri, R. (2014). Social media technology usage and customer relationship performance: A capabilities-based examination of social CRM. Journal of Business Research, 67(6), 1201-1208. https://doi.org/10.1016/j.jbusres.2013.05.002.

van Eck, N. J., \& Waltman, L. (2010). Software survey: VOSviewer, a computer program for bibliometric mapping. Scientometrics, 84(2), 523-538. https://doi.org/10.1007/s11192-0090146-3.

Vogel, R., \& Güttel, W. H. (2013). The dynamic capability view in strategic management: A bibliometric review. International Journal of Management Reviews, 15(4), 426-446. https://doi.org/10.1111/ijmr.12000. 
Wamba, S. F., Gunasekaran, A., Akter, S., Ren, S. J., Dubey, R., \& Childe, S. J. (2017). Big data analytics and firm performance: Effects of dynamic capabilities. Journal of Business Research, 70, 356-365. https://doi.org/10.1016/j.jbusres.2016.08.009.

Wang, Y., \& Byrd, T. A. (2017).Business analytics-enabled decision-making effectiveness through knowledge absorptive capacity in health care. Journal of Knowledge Management, 21(3), 517-539. https://doi.org/10.1108/JKM-08-2015-0301.

Wang, Y., \& Hajli, N. (2017).Exploring the path to big data analytics success in healthcare. Journal of Business Research, 70, 287-299. https://doi.org/10.1016/j.jbusres.2016.08.002.

Wedel, M., \& Kannan, P. K. (2016). Marketing Analytics for Data-Rich Environments. Journal of Marketing, 80(6), 97-121. https://doi.org/10.1509/jm.15.0413.

Xu, Z., Frankwick, G. L., \& Ramirez, E. (2016). Effects of big data analytics and traditional marketing analytics on new product success: A knowledge fusion perspective. Journal of Business Research, 69(5), 1562-1566. https://doi.org/10.1016/j.jbusres.2015.10.017. 